\title{
Biological Effects of Activation Products and Other Chemicals Released from Fusion Power Plants
}

by

J. A. Strand

T. M. Poston

September 1976

Prepared for the Energy Research and Development Administration under Contract E(45-1)-1830 
NOTICE

This report was prepared as an account of work sponsored by the United States Government. Neither the United States nor the Energy Research and Development Administration, nor any of their employees, nor any of their contractors, subcontractors, or their employees, makes any warranty, express or implied, or assumes any legal liability or responsibility for the accuracy, completeness or usefulness of any imformation, apparatus, product or process disclosed, or represents that its use would not infringe privately owned rights.

\author{
PACIFIC NORTHWEST LABORATORY \\ operated by \\ BATTELLE \\ for the \\ ENERGY RESEARCH AND DEVELOPMENT ADMINISTRATION \\ Under Contract $E(45-1)-1830$
}

\author{
Printed in the United States of America \\ Available from \\ National Technical Information Service \\ U.S. Department of Commerce \\ 5285 Port Royal Road \\ Springfield, Virginia 2215 \\ Price: Printed Copy \$5.00; Microfiche $\$ 2.25$
}


BNWL -2023

UC-20

\section{2}

BIOLOGICAL EFFECTS OF ACTIVATION PRODUCTS AND OTHER CHEMICALS RELEASED RROM FUSION PONER PLANTS

by

J. A. Strand

T. M. Poston

September 1976

Battelle

Pacific Northwest Laboratories

Richland, Washington 99352 



\section{PREFACE}

Fusion reactor technology has developed far enough to expect laboratory demonstration of practical levels of fusion employing the D-T reaction to occur in the early 1980s. Following that demonstration, and depending upon the national priorities for energy from D-T fusion, construction and operation of experimental reactors and demonstration power reactors could occur before the end of this century. Operation of the first commercial power plants could then follow, starting about 2010.

Development and adoption of a new power system eventually will require a description of the environmental effects in an environmental statement providing a comparison to the effects of competitive systems. In anticipation of that statement, an environmental analysis (BNWL-2010) has been prepared for the ERDA Division of Magnetic Fusion Energy. That analysis estimates the environmental effects of constructing and operating D-T fusion reactors as an economically competitive source of electricity in the 21 st century.

The analysis has four primary purposes:

1. To describe the general nature of the environmental effects,

2. To determine current ability to estimate the effects,

3. To determine methods for reducing the effects, and

4. To determine research necessary for increasing capability to define and reduce the effects.

Timely identification of needed research and methods for reducing effects will permit the performance of that research and the revision of conceptual fusion power plant designs before preparation of the program environmental statement. This would improve the quality of the environmental statements and could reduce the estimated adverse environmental effects due to fusion power plants.

The environmental analysis (BNWL-2010) concludes that the following assumed characteristics are the best set for the first operating fusion power plants:

- The D-T fusion reaction

- Large quantities of activation products

- Kilogram quantities of tritium in the plant systems

- Massive reactor structures

- Large 1ithium inventories

- Large inventories of liquid metals and salts
- Standard electricity generation

- Standard radioactive waste systems

- Large magnetic fields

- A self-contained fuel cycle

- Rural siting

Using these characteristics a reference reactor was analyzed to determine the environmental effects by using available concepts of plant subsystems designs that control interactions with the environment or by assumption that best current technology would be used in subsystems design.

Because this analysis does not take into account advances in both fusion and waste control technology during the next thirty years, the estimated effects probably are significantly higher than the actual effects will be for the first fusion power plants. The estimated environmental effects should be interpreted only as being the probable upper limit for the actual effects. 
Preparation of the fusion power plant environmental analysis required development and use of specially developed data and analysis methods not used in the preparation of current environmental statements for fossil and fission power plants. These data and analysis requirements are documented in a series of reference topical reports to make this information publicly available and to assure understanding of the basis for the conclusions made in the environmental analysis.

These reference topical reports summarize the state-of-the-art as applicable to preparation of environmental statements for fusion power plants. They present the data and analytical techniques used in the environmental analysis to estimate the interactions with the environment and the resultant environmental effects. This information then was analyzed for adequacy and the need was determined for additional research to assure satisfactory ability to prepare environmental statements for the fusion development program and experimental facilities in the early 1980s. Estimated environmental effects are presented in these reference documents only as necessary to illustrate use of the data and analytical techniques.

This report is one of those reference documents for the environmental analysis. The other documents in this series contain more details of the power plant concepts and the probable environmental effects of fusion power plants with the assumed characteristics listed above. These documents are available through the National Technical Information Service:

An Environmental Analysis of Fusion Power to Determine Related R\&D Needs, BNWL-2010

Review of Fusion Research Program: Historical Summary and Program Projections, BNWL-2011

Fuel Procurement for First Generation Fusion Power Plants, BNWL-2012

Current Fusion Power Plant Design Concepts, BNWL-2013

Reference Commericaì Fusion Power Plants, BNWL-2014

Siting Commercial Fusion Power Plants, BNWL-2015

Materials Availability for Fusion Power Plant Construction, BNWL-2016

Projected Thermodynamic Efficiencies of Fusion Power Plants, BNWL-2017

Tritium Source Terms for Fusion Power Plants, BNWL-2018

Management of Nontritium Radioactive Wastes from Fusion Power Plants, BNWL-2019

Methodology for Estimating Radiation Doses Due to Tritium and Radiocarbon Releases, BNWL-2020

Magnetic Field Considerations in Fusion Power Plant Environs, BNWL-2021

Biological Effects of Tritium Releases from Fusion Power Plants, BNWL-2022

Biological Effects of Activation Products and Other Chemicals Released from Fusion Power Plants, BNWL-2023

Safety Review of Conceptual Fusion Power Plants, BNWL-2024

An Investigation of the Transportation Requirements of Fusion Power Plants, BNWL-2025

Considerations of the Social Impact of Fusion Power, BNWL-2026

Environmental Impacts of Nonfusion Power Systems, BNWL-2027

Environmental Cost/Benefit Analysis for Fusion Power Plants, BNWL-2028

Biomagnetic Effects: A Consideration in Fusion Reactor Development, BNWL-1973

An Analysis of Tritium Releases to the Atmosphere by a CTR, BNWL-1938 
PREFACE . . . . . . . . . . . . . . . . . . . . . . . . . . .

SUMMAYY . . . . . . . . . . . . . . . . . . . . . . . . . . 1

1. BIOLOGICAL EFFECTS OF ACTIVATION PRODUCTS . . . . . . . . . . . . . . . . . . 3

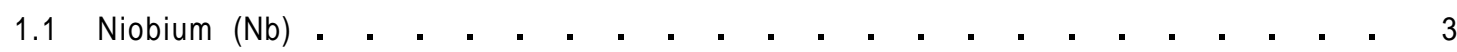

1.2 Vanadium (V) . . . . . . . . . . . . . . . . . . . . . . . 4

1.3 Aluminum $(\mathrm{A} 1)$. . . . . . . . . . . . . . . . . . . . . . . 5

1.4 Titanium $(T i)$. . . . . . . . . . . . . . . . . . . . . 6

1.5 Scandium $(\mathrm{SC})$. . . . . . . . . . . . . . . . 6

1.6 Stainless Steel . . . . . . . . . . . . . . . . 6

1.7 Chromium $(\mathrm{Cr})$. . . . . . . . . . . . . . . . . . . . . . 7

7.8 Cobalt $(\mathrm{Co})$. . . . . . . . . . . . . . . . . . . . . . 7

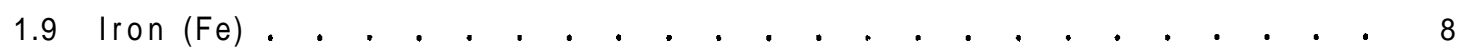

1.10 Manganese $(\mathrm{Mn})$. . . . . . . . . . . . . . . . . . 3

1.11 Conclusions . . . . . . . . . . . . . . . . . . . . . . . . . . 9

1.12 Future Research Needs . . . . . . . . . . . . . . . . . 10

2. BIOLOGICAL EFFECTS OF OTHER CHEMICAL RELEASES . . . . . . . . . . . . . . . 10

2.1 Biological Effects of Lithium. . . . . . . . . . . . . . 10

2.1.1 Lithium and Its Compounds . . . . . . . . . . . . . 11

2.1.2 Qualitative and Quantitative Analysis . . . . . . . . . . 11

2.1.3 Terrestrial Effects . . . . . . . . . . . . . . 11

2.1.4 Aquatic Effects . . . . . . . . . . . . . . . . . . 13

2.1.5 Human Effects . . . . . . . . . . . . . . . . 15

2.1.6 Conclusions . . . . . . . . . . . . . . . . . . . 15

2.1.7 Future Research Needs . . . . . . . . . . . . . . . . 10

2.2 Biological Effects of Sodium and Potassium . . . . . . . . . . . . 16

2.2.1 Sodium and Potassium and Their Compounds . . . . . . . . . . 16

2.2.2 Qualitative and Quantitative Analyses . . . . . . . . . . . 17

2.2.3 Elevation of Hydroxide Ion Concentration and Toxic Effects . . . 18

2.2.3.1 Terrestrial Effects . . . . . . . . . . . . . . 18

2.2.3.2 Aquatic Effects . . . . . . . . . . . . . . 18

2.2.4 Specific Ion Effects . . . . . . . . . . . . . . . . 20

2.2 .5 Conclusions . . . . . . . . . . . . . . . . . . . . 22

2.2.6 Future Research Needs . . . . . . . . . . . . . . . . 24 
2.3 Biological Effects of Beryllium . . . . . . . . . . . . . . . 24

2.3.1 Beryliium and Its Compounds . . . . . . . . . . . . . . 24

2.3.2 Qualitative and Quantitative Analysis . . . . . . . . . . . 24

2.3.3 Behavior and Effects of Beryllium in the Environment. . . . . . 25

2.3.3.1 Terrestrial Effects... . . . . . . . . . . . . 25

2.3.3.2 Human Effects. . . . . . . . . . . . . . . . . 25

2.3.3.3 Aquatic Effects : : : : : : : : : : : : : 25

2.3 .4 Conclusions . . . . . . . . . . . . . . . . . . . 26

2.3.5 Future Research Needs . . . . . . . . . . . . . 27

2.4 Salt Drift from Cool ing Towers . . . . . . . . . . . . . . . 27

2.4.1 Behavior and Effects of Salt Drift in the Environment . . . . . 27

2.4.1.1 Terrestrial Effects. . . . . . . . . . . . . . 27

2.4.1.2 Animals.......... . . . . . . . . . 28

2.4.1.3 Aquatic Effects . . . . . . . . . . . . . . . 28

2.4.2 Conclusions . . . . . . . . . . . . . . . . . . . . 28

2.4.3 Future Research Needs . . . . . . . . . . . . . . . . 29

2.5 Routine Releases to Water. . . . . . . . . . . . . . . . . 29

2.5.1 Effects of Routine Chemical Reieases in the Aquatic Environment . . 29

2.5.2 Conclusions . . . . . . . . . . . . . . . . . . . 30

2.5.3 Future Research Needs . . . . . . . . . . . . . . . . 30

BIBLIOGRAPHY . . . . . . . . . . . . . . . . . . . . . . . . . 31 


\section{SUMMARY}

Literature reviews indicate that existing information is incomplete, often contradictory, and of questionable value for the prediction and assessment of ultimate impact from fusion-associated activation products and other chemical releases. It is still uncertain which structural materials will be used in the blanket and first wall of fusion power plants. However, niobium, vanadium, vanadium-chromium alloy, vanadium-titanium alloy, sintered aluminum product (SAP), and stainless steel have been suggested. The activation products of principal concern will be the longer-lived isotopes of ${ }^{26} \mathrm{Al},{ }^{49} \mathrm{~V},{ }^{51} \mathrm{Cr},{ }^{54} \mathrm{Mn},{ }^{55} \mathrm{Fe},{ }^{58} \mathrm{Co},{ }^{60} \mathrm{Co},{ }^{93} \mathrm{Nb}$, and ${ }^{94} \mathrm{Nb}$. Such induced radioactivities may escape the reactor confines through neutron sputtering into or corrosion by liquid metal coolants. Activation products may also escape containment as aerosols under certain accident situations. Disposal of retrieved radioactive waste through burial may increase the potential for the environmental impact. The impact of fusion-associated activation products and other chemical releases on the terrestrial and aquatic ecosystem needs to be further determined. The biological transport of many of these elements has not been studied in terms of atmospheric dispersal, deposition and accumulation in soil, hydrologic transport, and accumulation in plants and animals.

Lithium released to the environment either during the mining cycle, from power plant operation or accident, may be in the form of a number of compound types varying in solubility and affinity for biological organisms. Hence, toxicity would appear to vary according to solubility and possibly pH shift. Where comparative data are presented, animal forms are more susceptible than plant forms; the embryonic and juvenile life stages demonstrating greater sensitivity than the adult animal. From the literature review, it is evident that the existing data base is of questionable value for the prediction and assessment of ultimate impact. The lack of information on source terms, in particular, complicates this problem. Also, present research has not treated the potential for adverse impacts from long-term, low-level exposures of the metal. The potential for biomagnification has not been defined.

The effects of a severe liquid metal fire or explosion involving Na or K will vary according to inherent abiotic and biotic features of the affected site. Saline, saline-alkaline, and sodic soils of arid lands would be particularly susceptible to alkaline stress. Grasslands soils contain greater quantities of humus which increase buffering capacity of the soil, alleviating akaline stress. The very acidic soil of forest regions would tend to neutralize alkaline insult. In marshlands, proximity to an aquatic biome would facilitate dilution; however, the ecology of wetlanas is extremely vulnerable to contamination from a liquid metal spill. Wetlands or marshlands often provide special habitats required for rare and endangered species, and are among the most productive biomes. Lentic (still-water) environments represent the most vulnerable of aquatic biomes; estuarine or marine coastal sites the least sensitive due to the greater buffering capacity of more saline waters. Present research, however, does not adequately deal with the environmental impact associated with liquid metal disasters. Of particular significance are the dynamics involved with the hydrolysis of alkali metal oxides in ecosystems and the fate of the alkali and hydroxide derivatives. 
Beryllium released to the environment during the mining cycle or reactor accident situation could te in the form of a number of compound types. Solubility and hence biological availability would vary with $\mathrm{pH}$, the presence of certain inorganic and organic compounds, and the physiochemical forms of these compounds; i.e., ionic, colloidal, or particulate. Beryllium toxicity was demonstrated in a variety of organisms including plants, animals, and man. Animals are usually as susceptible as plants. Evidence suggests that beryllium concentrates in both plant and animal forms with potential for biomagnification in food chains leading to man. Research needs include study of both acute and chronic exposures. The potential for biomagnification also needs to be defined. Studies over longer time perioas and at low levels need to he conducted to detect sublethal levels of stress.

Salt drift is not unique to fusion power plant designs. Salt drift. will contribute significantly to the accumulation of salinity in soils of arid regions, and to some degree in grasslands, with the potential for adverse impact on vegetation. Salt from cooling towers will not likely accumulate in forested regions. Cooling tower salt drift may contain trace quantities of arsenic, cadmium, lead, chromium, and mercury, and if threshold limits are exceeded, toxicity to animals as well as plants will result. Future research needs include provisions to better characterize the heavy metal constituents and other compounds comprising salt drift, as well as assessing their relative toxicities to indigenous flora and fauna. Tests under site specific conditions and utilizing indigenous species need to be conducted before the significance of impact may be predicted.

Adverse effects to aquatic species from routine chemical releases (biocides, corrosion inhibitcrs, dissolution products) may occur in the discharge of both fission and fusion power plant designs. The potential impact is reduced abundance or total loss of one or more species, and sometimes the substitution of undesired species. Mortality may be direct or indirect when small quantities accumulate within the flesh of affected omanisms. However, such I-outine chemical releases are wel7 characterized, and if releases are controlled, their actual impact will be minimal. Future research needs are to be applied on a site-by-site basis which includes provisions to determine the quality of cooling and receiving water to detect the presence and background levels of important chemical constituents; to determine by laboratory and field bioassay the potential acute and chronic effe ts of altered water quality and chemical discharges an susceptibie biota; and to determine the potential for accumulation and biomagnification of discharged chemicals in susceptible biota. 


\section{BIOLOGICAL EFFECTS OF ACTIVATION PRODUCTS}

Long-lived radioactive waste will result from operation of first generation fusion power plants. The primary source of such waste will be neutron activation of structural materials in the blanket and first wall that faces the plasma. Because of radiation damage, the first wall will be replaced and the removed material will be either sent to underground disposal or recycled. Burial increases the potential impact on land use, and recycle may create plant radiation problems or waste streams containing radioactivity. Such induced radioactivity may also escape the reactor confines through neutron sputtering into or corrosion by a liquid coolant. Coolant leakage during operation, or replacement and purification will yield radioactive waste for disposal. During certain severe accident situations, such neutron activated structural materials may escape plant containment as aerosols that will ultimately settle out to the ground, or dissolve in nearby water bodies.

The materials chosen for use in structural components include niobium, vanadium, vanadiumchromium alloys, vanadium-titanium alloys, sintered aluminum product (SAP), and stainless steel. In a 1000 megawatt thermal (MWt) fusion power plant, Steiner and Frass (1972) estimated that the radioactive inventory would include 155 niegacuries (MCi) of ${ }^{95} \mathrm{Nb}$ if niobium were used as the structural material, and $4.2 \mathrm{MCi}^{48} \mathrm{SC}$ if vanadium were used. For the UWMAK-I it was calculated that more than 80 percent of the activity in the first wall at shutdown would be attributed to the isotopes, ${ }^{51} \mathrm{Cr},{ }^{58} \mathrm{Co},{ }^{60} \mathrm{Co},{ }^{55} \mathrm{Fe}$, and ${ }^{54} \mathrm{Mn}$. The calculated activity after ten years was approximately $225 \mathrm{Ci} /$ kilowatt (UWFDM, 1973). The breeding of tritium in solid LiAl or SAP would result in ${ }^{26} \mathrm{Al}$ (Powell, et al., 1973) and other activation products implicated include ${ }^{51} \mathrm{Ti},{ }^{49} \mathrm{~V},{ }^{92} \mathrm{Nb}$, and ${ }^{94} \mathrm{Nb}$ (Young, et al., 1975).

The environmental transport of many of these elements has not been studied in terms of atmospheric dispersal, deposition and accumulation in soil, hydrologic transport, and accumulation in plants and animals. Very little data is readily available on the potential for bioaccumulation in food chains leading to man. This section includes a summary of the existing information on activation products.

\subsection{Niobium $(\mathrm{Nb})$}

The long half-lives of ${ }^{95} \mathrm{Nb}$ (35 days), ${ }^{94} \mathrm{Nb}\left(2 \times 10^{4}\right.$ years), and ${ }^{92} \mathrm{Nb}$ (10 days) creates concern regarding the ultimate effect of niobium on biological systems although niobium is considered a relatively unreactive metal. Niobium burns in the presence of air at $1472^{\circ} \mathrm{F}\left(800^{\circ} \mathrm{C}\right)$, and this implies that the isotopes could be dispersed as aerosols during an accident situation.

\section{Terrestrial Effects}

Vlamis and Pearson (1950) have shown that plants are able to absorb niobium and transfer it to the shoots. Niobium was reported to decrease the growth rates of laboratory mice over an 18 month period (Schroeder, et al., 1968). Female mice incurred reduced longevity, whereas, males remained unaffected in this respect. Tissue analyses demonstrated niobium accuniulations in the spleen and heart and a high incidence of hepatic tissue degeneration. Niobium used in Schroeder's work was administered orally. Furchner and Drake (1971) found that ${ }^{95} \mathrm{Nb}$ accumulated in the bones, kidneys, spleen, testes and liver of mammals, where radiological effects may be most detrimental. 
While the ecological role of niobium in terrestrial habitats is poorly understood, a mechanism for biomagnification for the element might possibly exist. Such a hypothesis needs to be verified by both laboratory and field experimentation.

\section{Aquatic Effects}

The role of niobium in aquatic ecosystems has received minimal examination. Niobium was found as a particulate in marine water at concentrations of $0.05 \mathrm{milligram} / \mathrm{kilogram}(\mathrm{mg} / \mathrm{kg})$. Polikarpov (1966) reported experimental concentration factors ranging from 335 for green algae up to 2000 for red algae (marine species). Molluscs were found to concentrate ${ }^{95} \mathrm{Nb}$ by a factor of 3000 in the byssus (a filamentous attachment structure) and 95-170 in the shell. Crustaceans (Malocostracea) maintained the highest concentration in the gills (19-150) and in the exoskeleton (60-100). Muscle and viscera concentration factors were quite low. Eisenbud's (1973) concentration values agree with Polikarpov (1966), although he found values up to 2900 for plant forms.

Niobium can be concentrated in various forms of life but little has been done to define its effects upon biota, particularly freshwater inhabitants. Lack of such definition is evident for both stable and radioactive isotopes of niobium, and the effects of niobium should be studied if it becomes a major constituent in fusion reactors.

\subsection{Vanadium (V)}

Natural concentrations of vanadium in the air range from $0.22-0.80 \mathrm{ng} / \mathrm{m}^{3}$, with higher concentrations observed near industrial facilities (NAS, 1974). Airborne vanadium compounds resulting from a massive liquid metal fire could possibly exceed these levels locally and increase the potential for adverse biological interaction. A radiological hazard could be imposed by ${ }^{49} \mathrm{~V}$ because of a half-life of 330 days. Such a radiological hazard due to deposition of ${ }^{52} \mathrm{~V}$ is small because of a short half-life of 3.77 minutes. Stable vanadium is produced as a decay product of ${ }^{51} \mathrm{Ti}$ and ${ }^{51} \mathrm{Cr}$, both activation products of other potential structural materials for fusion reactors.

\section{Terrestrial Effects}

Welch and Huffman (1973) found no difference in growth yields of lettuce and tomatoes grown in nutrient solutions with 0.04 and $50.0 \mathrm{milligram} / \mathrm{milliliter}(\mathrm{mg} / \mathrm{ml})$ vanadium. However, definitive limits of vanadium toxicity to plants have not received much attention. McKee and Wolfe (1971) cited levels of 10-20 mil1igram/liter ( $\mathrm{mg} / 1)$ vanadium as harmful to soybean and $\mathrm{flax}$, and $50 \mathrm{mg} / \mathrm{l}$ of metavanadate ion $\left(\mathrm{V}^{-3}\right)$ as injurious to sugar beets.

Vanadium has been recognized as a potential health hazard to humans. Vanadium has also been linked to the suppression of many enzymatic processes in mammals. Toxicity was found to be dependent upon mode of absorption with parenteral mechanisms of adminstration having greater effects than respiratory or digestive pathways. Lethal doses of the element range from 1.0 to $190 \mathrm{mg} / \mathrm{kg}$ body weight for various laboratory animals (McKee and Wolf, 1971).

\section{Aquatic Effects}

Vanadium has been reported in a concentration range of 0.3 to $<20.0$ microgram/1iter $(\mu \mathrm{g} / 1)$ in most fresh waters of the U.S. Extreme levels of $220 \mathrm{mg} / 1$ have been recorded in Wyoming (NAS, 1974). Sea water values are reported over a 'range of 2-29 $\mu \mathrm{g} / 1$. Vanadium is most soluble in the tetra- and penta-salt form. The vanadyl cation (VO) and vanadate anion $\left(\mathrm{VO}_{4}\right)$ 
are also soluble. Vanadium was shown to be an essential element for the green alga Scenedesmus obliquus. Ascidians have been recognized for their ability to concentrate vanadium. Seinehart, et a 1. (1974) reported concentrations of 9000 in Perophora annectens. Polikarpov (1966) reported concentration factors of 10-300 for brown algae, 1000 for noncalcareous algae, 100 in the soft tissues of invertebrates and $20 \mathrm{in}$ the soft tissues of vertebrates.

Specifications of vanadium toxicity are relatively few. Tarzwell and Henderson (1956) found the $96 \mathrm{i}$ hour Median Tolerance 1imit (TLm) for fathead minnow, Pimephales promelas, to be $4.8 \mathrm{mg} / 1$ in soft water and $30 \mathrm{mg} / 1 \mathrm{in}$ hard water when vanadyl sulfate was used. Similar tests performed with the bluegiil sunfish, Lepomis macrochirus, gave a TLm value of $6 \mathrm{mg} / 1 \mathrm{in}$ soft water and $55 \mathrm{mg} / \mathrm{i}$ in hard water.

\subsection{Aluminum (A1)}

In the accident situation involving a fusion design employing LiAT or SAP, oxidation of hot LiAl would likely produce airborne ${ }^{26} \mathrm{Al}_{2} \mathrm{O}_{3}$ particles, as well as $\mathrm{Li}_{2} \mathrm{O}$. The principal compound or interest here, ${ }^{26} \mathrm{Al}_{2} \mathrm{O}_{3}$, is not highly soluble in neutral or slightly acid solutions, and therefore, is not considered to be highly mobile in surface soils or surface waters. However, over a period of time, dissociation to a more soluble form could resuit in significant translocation with potential for adverse biological interactions. The very long half-1ife of ${ }^{26} \mathrm{Al}$ $\left(7.4 \times 10^{5}\right.$ years $)$ would necessitate long-term management of the waste.

\section{Terrestrial Effects}

When nutrient cations ( $\mathrm{Ca}, \mathrm{Mg}$, and $\mathrm{K}$ ) are lacking as in common acid soils, water soluble aluminum at concentrations as low as 1 to 2 parts per million (ppm) inhibited growth of rice roots (Cate and Sukhai, 1964). Effects of higher concentrations on other cereals included chlorosis of older leaves, limited and distorted root growth, and root discoloration. Toxicity symptoms resembled calcium deficiency, since aluminum reduced both absorption and accumulation of calcium, and restricted calcium transport to the shoots.

Toxicity symptoms of aluminum have been reported in animals, but at generally higher levels; a constant intake of approximately $42.9 \mathrm{ppm}$ of aluminum oxide was apparently the cause of death in domestic cattle (Pugh, 1945). An average daily dose of 2 milligram (mg) of aluminum did not harm rats (Anon,, 1950). The total aluminum in the normal diet of humans is estimated at 10 to $100 \mathrm{mg}$ per day (Browning, 1961). However, very little of such ingested aluminum is absorbed in the alimentary tract,

\section{$\underline{\text { Aquatic Effects }}$}

Bringmann and Kuhn (1959) studied the threshold effects of $\mathrm{AlCl}_{3}$ on various aquatic organisms during an exposure of 4 days at 75 to $80^{\circ} \mathrm{F}\left(23\right.$ to $\left.27^{\circ} \mathrm{C}\right)$. Daphnia spp. withstood a concentration of 1000 ppm as aluminum; while the alga, Scenedesmus spp. demonstrated toxic effects at 1.5$2.0 \mathrm{ppm}$. In contrast, the threshold concentration for Daphnia spp. in Lake Erie waters at $77^{\circ} \mathrm{F}\left(25^{\circ} \mathrm{C}\right)$ was found to be less than $7 \mathrm{ppm}$ over 64 hour exposure (Anderson, 1950). Young eels, Anguilla rostrata, died in 3.6 hours exposed to $2.7 \mathrm{ppm}$ aluminum as $\mathrm{AlCl}_{3}$ (Doudoroff and Katz, 1953). 


\subsection{Titanium $(\mathrm{Ti})$}

Titanium is the tenth mast abundant element found (as oxide material) in the earth's crust. Aside from radioactive ${ }^{57} \mathrm{Ti}$, stable isctopes of titanium may be encountered as decay products of ${ }^{49} \mathrm{~V}$ and ${ }^{48} \mathrm{Sc}$ (activation production of other elements under consideration for fusion reactors). Biologically, titanium has not been attributed to any nutritional role in plants or animals. Titanium's ecological role requires more attention if titanium is used in large quantities in fusion reactors, as indicated by the relative lack of data available.

\section{Terrestrial Effects}

Sugar beets were adversely affected by $i 2 \mathrm{mg} / 1$ titanium in nutrient solutions (Hewitt, 1953). Titanium has been shown to be totally inert in the human digestive tract with minimal absorption, and it seems reasoriable to speculate that titanium would behave in a similar manner with other mammais.

Aquatic Effects

Po?ikarpov (1956) reported concentration factors of 90-10,000 for 6 species of brown algae, 1,000 for noncalcareous algae, 1,000 in the soft tissue of invertebrates, and 40 for fish tissue (all marine varieties).

Median toxic thresholds for titanium chloride are reported at $2.0 \mathrm{mg} / 1$ for Scenedesmus spp., 4-6 mg/1 for Daphnia spp. and $40 \mathrm{mg} / 1$ for the protozoan Microregma spp., (Bringmann and Kuhn, 1959). Tarzweil and Henderson (1956) found that the 96 hour TLm for the flathead minnow, Fimephales promelas, was $8.2 \mathrm{mg} / 1 \mathrm{in}$ salt water and $120 \mathrm{mg} / \mathrm{i}$ in hard fresh water.

\subsection{Scandium $(\mathrm{Sc})$}

The isotopes ${ }^{46} \mathrm{Sc},{ }^{47} \mathrm{Sc}$, and ${ }^{48} \mathrm{Sc}$ may all be produced by activation if a V-20 titanium alloy is used as the first wa??material. All are radioactive isotopes with relatively long halflives and decay by beta emission to form stable isotopes of titanium. It is estimated that ${ }^{48}$ Sc would account for 12.1 curie/kilowatt ( $\mathrm{Ci} / \mathrm{kW}$ ) for a 10 year exposure (UWFDM, 1973).

Ecological behavior of scandium is poorly understood. Menzel (1965) reported a relative concentration factor of scandium in crop plants of less than 0.01 . Scandium was applied in water soluble forms to soils after which plant content of scandium was determined. Sax (1963) cited scandium toxicity as unxnown, but scandium does chemically resemble the rare earth elements and may behave similarly. Such speculation should be scientifically verified before a more definitive assessment can be mace.

\subsection{Stainless Steel}

The principal activaticn products of 316 stainless steel include ${ }^{51} \mathrm{Cr},{ }^{58} \mathrm{Co},{ }^{60} \mathrm{Co},{ }^{55} \mathrm{Fe}$, and ${ }^{54} \mathrm{Mn}$. All have relatively long half-lives, and most are considered biologically active elements. 


\subsection{Chromium (Cr)}

Chromium-51 (half-life of 2i.8 days) decays to stable ${ }^{51} \mathrm{~V}$ by electron capture. Stable ${ }^{52} \mathrm{Cr}$ may also be produced by beta decay of activated ${ }^{52} \mathrm{~V}$. Chromium does not occur freely in nature, but the ions $\mathrm{Cr}^{+2}, \mathrm{Cr}^{+3}, \mathrm{CrO}_{2}^{-1}, \mathrm{CrO}_{3}^{-3}$, and $\mathrm{CrO}_{7}^{-2}$ are often encountered in effluents from industrial processes. Of the trivalent chromic salts, the chloride, nitrate and sulfate are soluble in water; the hydroxide and carbonate are insoluble. Of the hexavalent salts, only sodium, potassium, and ammonium chromate are considered soluble in water. The corresponding dichromate salts are also soluble in water.

\section{Terrestrial Effects}

Chromium is present in soils and plants in trace quantities, but there is no evidence that suggests plants concentrate the element. Plants are considered to be more susceptible to chromium toxicity than animals. Trivalent chromium exhibited a slight toxicity to agricultural crops at concentrations of 3.4 to $17.3 \mathrm{mg} / 1$ (Klintworth, 1952). Varying degrees of chlorosis were observed in oats treated with 5.0 to $10 \mathrm{mg} / 1$ potassium dichroniate, while 15 to $50 \mathrm{mg} / 1$ greatly impaired growth (Hewitt, 1953). Sedova (1958) reported that concentrations of chromium in excess of $1.0 \mathrm{mg} / \mathrm{kg}$ soil inhibited nitrification.

In experiments with rats and dogs, Byerrum (1960), Mackenzie, et al. (1957, 1958), Decker, et al. (1956, 1958) and Anwar, et al. (1960), demonstrated that little chromium was retained in body tissues when either trivalent or hexavalent chromium was administered at $5 \mathrm{mg} / 1$ or less in drinking water. At $7.7 \mathrm{mg} / 1$ or more, all tissues showed a significant increase in accumulation. At $25 \mathrm{mg} / 1$, those organisms receiving hexavalent chromium demonstrated an average tissue chromium content eight times higher than organisms receiving trivalent chromium. However, even at $25 \mathrm{mg} / 1$, no adverse effect on food consumption or weight gain was recorded.

\section{Aquatic Effects}

Polikarpov (1966) reported concentration factors of $260-295$ for ${ }^{51} \mathrm{Cr}$ in freshwater plants while concentration factors of 100-120,000 were cited for six species of marine algae.

For hexavalent chromium, Anderson (1944) reported the toxic threshold of Daphnia magna to be $<1.0 \mathrm{mg} / 1$; while for trivalent chromium, Anderson (1958) indicated the toxic threshold for Daphnia magna was $1.2 \mathrm{mg} / 1$. Bringmann and Kuhn (1959) showed that the toxic threshold for Daphnia magna to trivalent chromium was $42 \mathrm{mg} / 1$.

For fish, hexavalent chromium of 5 to $520 \mathrm{mg} / 1$ is reported by McKee and Wolf (1971) to be toxic for a variety of species; whereas, trivalent chromium of 1.2 to $5.2 \mathrm{mg} / 1$ is reported to be toxic for a limited number of species. However, in a series of experiments where juvenile chinook. salmon were exposed to either $0.2 \mathrm{mg} / 1$ hexavalent or trivalent chromium, Olson (1958) found that test fish exposed to the hexavalent form demonstrated reduced growth and increased mortality, whereas, test fish exposed to the trivalent form showed no observable effect.

\subsection{Cobalt (Co)}

${ }^{58} \mathrm{Co}$ and ${ }^{60} \mathrm{Co}$ account for 29 and $4.7 \mathrm{Ci} / \mathrm{kW}$ for a 10 year exposure of 316 stainless steel in the UWMAK-I design (UWFDM, 1973). ${ }^{58}$ Co (half-life 72 days) and ${ }^{60}$ Co (half-life 5.25 years) decay respectively to ${ }^{58} \mathrm{Fe}$ and ${ }^{60} \mathrm{Ni}$, both stable isotopes. Cobalt salts may be both divalent and trivalent. The divalent salt is relatively stable, whereas, the trivalent salt is unstable and is a strong oxidizing agent. 


\section{Terrestrial Effects}

While plants require small quantities of cobalt as a micronutrient, excessive amounts produce detrimental effects. Concentrations of $2.0 \mathrm{mg} / 1$ cobalt sulfate were found to cause stunting and withering in tomato plants and $10.7 \mathrm{mg} / 1$ was lethal (Meinck, et al., 1956). Flax plants exhibited toxic effects to cobalt at $1.0 \mathrm{mg} / 1$ (McKee and Wolf, 1963). Concentrations of 5.9, 14.7 , and $29.5 \mathrm{mg} / 1$ were also found toxic for sugar beets, tomatoes, and other crop plants in sand culture (Hewitt, 1953).

Cobalt may be considered to have a relatively low toxicity for animal forms. A lethal dose for dogs was found to be $30 \mathrm{mg} / \mathrm{kg}$ body weight (Anon., 1950) whereas, $0.9 \mathrm{mg} / \mathrm{kg}$ produced toxic effects in dairy calves (Ely, et al., 1948). The lethal dose for chicks was reported by Turk and Kratzer (1960) to be $50 \mathrm{mg} / \mathrm{kg}$ body weight, and impaired growth was monitored at levels as low as $5 \mathrm{mg} / \mathrm{kg}$ body weight.

\section{Aquatic Effects}

Polikarpov (1966) reported that freshwater algae concentrated ${ }^{60}$ Co over a range of 250 to 238,000 times above ambient levels. Freshwater vascular plants concentrated the isotope in the range of 3,490 to 18,665 . Concentration factors in marine algae ranged between 15-740. Marine invertebrates, however, were reported to concentrate the element up to 20,005 times. Values for marine fish were cited to be 14 to 560 .

Cobalt concentrations of $1.0 \mathrm{mg} / 1$ were not found to be harmfui to yearling tench, carp, rainbow trout, and char, or to crustacea, worms, and insect larvae comprising the food base of these fish (Schweiger, 1961). Jones (1939) found the lethal concentration for stickleback, Gâsterosteus aculeatus, to be $10 \mathrm{mg} / \hat{\imath}$. A letnal concentration of cobalt chloride in the killifish. Fundulus spp., was reported to be $16 \mathrm{mg} / 1$ by McKee and Wolf (1963) who also reported $10 \mathrm{mg} / 1$ cobalt nitrate to be lethal for stickleback.

\section{$1.9 \underline{\operatorname{lron}(\mathrm{Fe})}$}

${ }^{55} \mathrm{Fe}$ is estimated to account for $140 \mathrm{Ci} / \mathrm{kW}$ over a 10 year exposure in the UWMAK-I design. (UWFDM, 1973), ${ }^{55} \mathrm{Fe}$ has a half-life of 2.6 years and decays to the stable isotope ${ }^{55} \mathrm{Mn}$.

\section{Terrestrial Effects}

Iron is rarely reported to impose a hazard in terrestrial habitats. Iron is a problem in plarits only when it is deficient. Iron is an essential constituent of animal diets so dietary changes may affect the health of domesticated animals. McKee and Wolf (1963) reported that dairy cows drink less and produce less milk when their source of drinking water contains high iron content.

\section{Aquatic Effects.}

Most iron salts are soluble in water, hence, are biologicaily available. However, alkaline waters tend to oxidize ferrous ions to ferric ions resulting in the precipitation of insoluble oxides and hydroxides. Mckee arid Wolf (1963) reported that algae and phytoplankton concentrated ${ }^{59} \mathrm{Fe}$ from 720 to 200,000 times above ambient concentrations. 
Southgate (1948) indicated that toxicity to iron and iron salts is dependent upon whether it is in solution or suspension. Generally, iron as ferrous ions is considered to be more toxic than iron as ferric ions. McKee and Wolf (1963) reported that death of tench, pike and trout occurred at $1-2 \mathrm{mg} / 1$ iron at $\mathrm{pH}$ of 5.0 to 6.7. However, ferric salts, if precipitated at higher $\mathrm{pH}$, may impose a hazard to benthic communities and demersal spawning fish species. NAS-NAE (1972) has recommended that iron concentrations in surface waters do not exceed $0.3 \mathrm{mg} / 1$.

\subsection{Manganese $(\mathrm{Mn})$}

Manganese-54 (half-life of 310 days) is reported to account for $24 \mathrm{Ci} / \mathrm{kW}$ in the stainless steel blanket structure of UWMAK-I over a 10 year exposure (UWFDM, 1973). Manganese-54 decays by electron capture to stable ${ }^{54} \mathrm{Cr}$. Manganese has similar chemical properties as iron, and the sulfate, nitrate, and chloride salts are all relatively soluble in water. The oxides and hydroxides are considered relatively insoluble.

\section{Terrestrial Effects}

Manganese is regarded as an essential micronutrient for plants; however, manganese toxicity may occur in soils if the $\mathrm{pH}$ drops below 5.5 rendering insoluble manganese more soluble. Although effect varies by species, manganese toxicity is generally manifest by crinkling of leaf margins with progressive necrosis of leaves and stems. McKee and Wolf (1963) reported that manganese was harmful for most plants over a range of 1 to $25 \mathrm{mg} / 1$. However, flax and oats were adversely affected at high concentrations of 50 to $500 \mathrm{mg} / 1$.

Increased quantities of ingested manganese is believed to cause an imbalance of other essential minerals in mammals. A continuous excess of manganese has been reported to cause an infectious anemia in horses. Manganese was believed to oxidize vitamin B in the horse, producing the disease avitaminosis (Russell, 1944). However, intake of manganese at levels as high as $6 \mathrm{C} 0 \mathrm{mg} / \mathrm{kg}$ body weight was not harmful to either cattle or birds (McKee and Wolf, 1963).

\section{Aquatic Effects}

Manganese is concentrated 10,500 to 42,000 times above the ambient level by freshwater algae (Harvey, 1974). Polikarpov (1966) reported that manganese was concentrated by marine algae from 20-20,000 times, while concentration factors for 300 planktonic species ranged between 340 to 1700 . Concentration factors for fish were estimated to range between 70 to 126,000 times; for molluscs, between 600 to 550,000 times.

The toxic threshold concentration for the flatworm, Polycelis nigra, was reported by Jones (1940) to be $700 \mathrm{mg} / 1$ as manganese chloride and $660 \mathrm{mg} / 1$ as manganese nitrate. Other aquatic invertebrates were not harmed by $15 \mathrm{mg} / 1$ of manganese over a 7 day exposure (Schweiger, 1957). McKee and Wolf (1963) cited concentrations of manganese over a range of 15 to $2700 \mathrm{mg} / \mathrm{l}$ as being toxic to various species of fish. Permangandte salts were reported to kill fish in 8 to 18 hours at concentrations as low as 2.2 to $4.1 \mathrm{mg} / 1$ (Oshima, 1960 and Iwao, 1960).

\subsection{Conclusions}

The spectrum of neutron induced activation products in structural materials of fusion power plants may differ significantly from that of current BWR or PUR designs. It is still uncertain which structural materials will he used in the blanket and first wall of fusion reactors; however, 
niobium, vanadium, vanadium-chromium alloy, vanadium-titaniusi alloy, sintered aluminum product (SAP), and stainless steel have been suggested. The activation products of principal concern will be the longer-lived isotopes of ${ }^{26} \mathrm{Al},{ }^{49} \mathrm{~V},{ }^{51} \mathrm{Cr},{ }^{54} \mathrm{Mn},{ }^{55} \mathrm{Fe},{ }^{58} \mathrm{Co},{ }^{60} \mathrm{Co},{ }^{93} \mathrm{Nb}$, and ${ }^{94} \mathrm{Nb}$. Such induced radioactivities may escape the reactor confines through neutron sputtering into, or corrosion by liquid metal coolants. Activation products may also escape containment as aerosols under certain accident situations. Disposal of retrieved radioactive waste through burial may increase the potential for environmental impact.

However the above literature review indicates that the existing data base is incomplete and often contradictory, and is of questionable value for the prediction and assessment of ultimate impact. The environmental transport of many of these elements has not been studied in terms of atmospheric or hydrologic dispersal, deposition and accumulation in soils or sediments, and accumulation in plants and animals. Very little data are readily available on the potential for bioaccumulation in food chains leading to man. Lack of estimates of the quantities of principal activation isotopes released in waste streams or under accident conditions further restricts assessment at this time.

\subsection{Future Research Needs}

Estimates of the quantities of fusion associated activaticn products released to the environment as well as their physical/ chemical form need to be established. Important pathways of dispersal to both terrestrial and aquatic ecosystems must also be identified. For both acute and chronic release conditions, estimates of concentration factors and turnover rates in both abiotic and biotic compartments of natural ecosystems need to be confirmed. Temporal and spatial variations must be followed and trophic relationships studied. Since mariy fusion associated activation products are concentrated above ambient levels in both plant and animal forms, the potential for biomagrification must also be defined. The radiotoxicity of activation products identified as micronutrients in biological systems also needs to be assessed,

\section{BIOLOGICAL EFFECTS OF OTHER CHEMICAL RELEASES}

\subsection{Biological Effects of Lithium}

Lithium (Li) is routinely used in industry and has a iong history of mining, refining, and processing. Environmental quälity staridards have been defined and adequate technology is available to permit design of waste treatment systems that assure compliance with applicabie air and water quality regulations.

However, significant releases of $\mathrm{Li}$ could occur during accidents. This may create a different impact than the pest routine small releases. To assess with assurance the effect of Li reieases, it is necessary to know how readily the metal is metaboitized by biological organisms, and at what ievels toxicity may be expected. Entry of Li into the food chain or food web with biomagnification could present a hazard to man. However, few studies relevant to this need have been undertaken. 


\subsubsection{Lithium and Its Compounds}

Lithium ( $\mathrm{Li}$ ) is one of the alkali metals and is chemically related to sodium ( $\mathrm{Na}$ ) and potassium $(\mathrm{K})$; being found only in a few minerals and certain spring waters. Extremely reactive, the metal does not occur naturally in the elemental state. When purified, it must be maintained free of interaction with oxygen and water. It is used in metallurgy, for medicinal purposes, in some types of glass, as lithium hydroxide in storage batteries, and as a water conditioner in light water reactors.

Lithium forms a nitride by direct combination with nitrogen at ordinary temperatures. Lithium chloride ( $L i C 1$ ) is produced directly from Li metal and is very soluble in water, alcohol, and certain other nonaqueous solvents. Lithium carbonate $\left(\mathrm{Li}_{2} \mathrm{CO}_{3}\right)$ is a light, white alkaline compound that is readily solubilized in water. Lithium forms the moderately soluble salt lithium fluoride ( $L \mathrm{iF}$ ), and the less soluble lithium oxide $\left(L \mathrm{i}_{2} \mathrm{O}\right)$, both of which have been identified as possible combustion products released to the environment in the event of a massive liquid metal fire or explosion.

\subsubsection{Qualitative and Quantitative Analysis}

As with sodium $(\mathrm{Na})$ and potassium $(\mathrm{K})$, lithium $(\mathrm{Li})$ is most readily determined in trace quantities by flame photometry (APHA, 1971). The measurement is performed at a wave length of 671 millimicron ( $\mu \mathrm{m})$ with a Perkin-Elmer Model 52-C flame photometer or a Beckman Model DU spectrophotometer equipped with photomultiplier tube and flame accessory.

The minimum $L i$ concentration detectable by the flame photometric method is of the order of $0.1 \mathrm{mg} / 1$. Barium $(\mathrm{Ba})$, strontium $(\mathrm{Sr})$, and calcium $(\mathrm{Ca})$ are known to interfere in the flame photometric determination of $L i$, but can be removed by the addition of a sodium sulfate--sodium carbonate solution which precipitates $\mathrm{BaSO}_{4}, \mathrm{SrCO}_{3}$, and $\mathrm{CaCO}_{3}$. The quantity of either sodium or magnesium must not exceed 10 milligrams in the aliquot taken for analysis.

In general, the unknown $\mathrm{Li}$ concentration is determined by direct intensity measurement at a wave length of $671 \mathrm{~m} \mu$. Development of a standard curve relationship is necessary. The unknown, distilled water blank $(\mathrm{mg} / \mathrm{L} \mathrm{Li})$ and the Li standards are analyzed as nearly simultaneously as practical.

The concentration of $\mathbf{L} \mathbf{i}$ in the unknown is determined from the calculations:

$$
\mathrm{mg} / 1 \mathrm{Li}=\frac{u g \mathrm{~L} i}{\mathrm{ml} \text { sample }}
$$

The $L i$ concentration can be determined with an accuracy of $\pm 0.0-0.2 \mathrm{mg} / 1$ over a range of 0.7 $1.2 \mathrm{mg} / 1$.

\subsubsection{Terrestrial Effects}

Plants sensitive to Na will generally show a sensitivity to Li. Lithium toxicity in citrus trees has been identified in Santa Barbara County, California. In greenhouse experiments, 2 to $5 \mathrm{mg} / 1$ lithium sulfate caused the appearance of toxic symptoms in orange seedlings. In the 
field, 1,2 , and $4 \mathrm{mg} / \mathrm{i}$ of lithium chloride in the soil have caused Li toxicity. irrigation waters in the vicinity contained $0.045-0.080 \mathrm{mg} / 1 \mathrm{~L} i$. Lithium poisoning probably resuited from the accumulation in the soils of toxic concentrations aver a relatively long period of time (Mckee and Kolf, 1963).

Hansen and Overstreet (1952) studied the effects of alkaline eartn salts on the growth of roots and hypocotyl of the radish. It was found that chlorides of the alkali group diminished elongation in the order $\mathrm{LiCl}>\mathrm{CSCl}>\mathrm{RbCi}>\mathrm{NaCl}$. The depressing effect of alkali-salts was not due primarily to increased osmotic pressure of the culture medium, but to a specific inhibitory effect by the alkaline ions. hansen and Overstreet (1952) also reported that Li as LiCT was toxic to citrus trees at 0.05 to $0.1 \mu \mathrm{g} / 1$.

Bertrand (1949) studied the distribution of $\mathrm{Li}$ in seeds. Forty widely diverse species were examined. In general, the seeds contained a lower percentage of $L i$ than the remainder of the plant.

The absorotion of Li in rye seedlings was investigated by Michael and Wilberg (1951). The rye was grown in pure sand and the comparative absorption: of $\mathrm{Li}$ and $\mathrm{K}$ determined. The quantity of $\mathrm{Li}$ was found to vary from 20 to 120 percent of $\mathrm{K}$; the highest ratio occurred under conditions of poisoning with urethane. The ratio increased with age of the plants, with increase of $\mathrm{CO}_{2}$ in the plant atmosphere, and with decrease in size of seeds. It had a maximum value at $\mathrm{pH}$ 5-6 in the medium and was not affected by either light or dark conditions.

Yamagata and Karobe (1951) studied the absorption of Li, Cs arid Rb in plants. They found that the rate of absorption of $L i$ by rice decreased as the concentration in the water of cultivation ircreased. While that of $C s$ was found to increase as the concentration in the water increased, the rate of absorption of $\mathrm{Rb}$ had no relation to the concentration in the water.

In litnium fluoride, toxicity attributable to the fluoride ion may also result. Plants have been reported to concentrate fluoride. Leone, et al. (1948) demonstrated that in acid soils containing only a few parts per million soluble fluoride, roots accumulated 1000 to 6003 ppm fluoride, while several hundred parts per million were translocated to the leaves. Brewer, et al. (1959) also found that citrus trees accumulated significant quantities of fluoride from nutrient solutions. but inferred that such absorption was unlikely under field conditiuns. Macintire, et al. (1942) found when superphosphates were added to soil to improve fertility, their righ fluoride content did not add significantly to fluoride content in plants grown on such soils.

Treshow (1970) indicated that entry to the plant occurs through the leaf stomata, where it passes directly into the cell or is dissolved in water and is transported through vascuiar tissues to accumulate in the leaf tips and margins. Accumilation of toxic concentrations results in necrosis, chlorosis, or both. Fluoride has been postulated to affect the fundamental activity of enzymes essential to such plant precesses as respiration, photosynthesis, carbohydrate metabolism, protein synthesis, celi wall formation, energy balance, and nucleotide and nucleic acid synthesis.

Fluoride also affects growth of plants. In greenhouse studies of srange trees exposed to 1-5 ppb fluoride as an aerosol for 26 months, Brewer (1960) established that leaf size was reduced 30 percent, linear shoot growth was reduced 15 percent, and tree height and crosn volume were also reduced, Field studies conducted by Anderson (1966) have shown that ieaf size 
of woody plants such as aspen and Oregon grape were also reduced significaniiv when exposed to atmospheric flucride. However, Aso (1906) concluded that small quartities of sodium fluoride stimulated growth of barley and pea plants. Treshow, et al. (1967) a? so reported enhanced vegatative growth resulted when bean plants were exposed to aerosols containing $0.5-4 \mathrm{~g} / \mathrm{m}^{3}$ fluoride.

Adverse effects on plant reproduction have also been reported. In greenhouse experiments on citrus yields, Leonard and Graves (7966) demonstrated a 27 percent decrease in average yield per tree with each $50 \mathrm{ppm}$ increase in atmospheric fluoride ccncentration. Yield reductions were partly attributed to visible chlorosis which appeared when foliar fluoride levels exceeded 20-30 ppm.

Fewer studies are available on the influence of $\mathrm{Li}$ on animal forms. The tolerance of Drosophila melanogaster to $\mathrm{LiCl}, \mathrm{NaH}_{2} \mathrm{PO}_{4}, \mathrm{KH}_{2} \mathrm{PO}_{4}, \mathrm{KCL}$, and $\mathrm{NaCl}$ was studied by King (1953). $\mathrm{Li}^{+}(0.02 \mathrm{M})$ was far more toxic, whille $\mathrm{K}^{+}$was slightly more toxic than $\mathrm{Na}^{t}$ at higher concentrations (0.4M). King also concluded that inhibition was specific rather than due to osmotic or hydration phenomiena. The time required for the completion of development of Drosophila reared on a culture medium containing $0.02 \mathrm{M} \mathrm{LiCl}$ was increased two to threefold. Characteristic abnormalities were produced in male terminalia and wing venation.

The effect of lithium carbonate on egg shell formation and serum calcium level of the hen was studied by Creek, et al. (1971). The inclusion of lithium carbonate in the diet of hens at levels of 282-685 $\mathrm{mg}$ of $\mathrm{Li}$ per $\mathrm{kg}$ of diet produced diarrhea, excess salivation, regurgitation, and production of shell-less eggs as early as 24 hours after being placed on the experimental diet. Lithium also decreased serum Ca levels; however, soft shelled eggs were produced before any reduction in serum $\mathrm{Ca}$ was detectable. Lithium seemed to inhibit shell deposition in some other manner.

The oral $L_{50}$ for lithium flucride in guinea pigs was reported by Simonin and Pierron (1937) to be approximately $200 \mathrm{mg} / \mathrm{kg}$ of body weight. Fluoride in drinking water at concentrations of $50 \mathrm{mg} / 1$ has caused chronic poisoning in sheep (Boddie, 1944).

\subsubsection{Aquatic Effects}

Lithium is a minor constituent of minerals and usually is present in fresh waters at concentrations below $10 \mathrm{mg} / 1$. Brines and thermal waters contain higher Li levels.

In the protozoan Microegma, food intake was inhibited at a concentration of LiCl of $66 \mathrm{mg} / 1$ (1959). Employing Escherichia coli and Scenedesmus spp. as test organisms, no toxic effects were observable at concentrations of $<100 \mathrm{mg} / 1$ (1959).

Kariander and Krauss (i972) demonstrated that under optimial growtr conditions of light, $\mathrm{CO}_{2}$ and temperature, concentrarions up to $100 \mathrm{mg} / 1$ of Li were not inhibitory to growth of Chlorella vennielli. At $1000 \mathrm{mg} / 1 \mathrm{Li}$, the autotrophic growth rate was reduced to 52 percent of the control.

Anderson (1948) found the threshold concentration for immobilization of Daphnia magna in iake Erie water to be $<7.2 \mathrm{mg} / \mathrm{l}$. In River Havel water at $73^{\circ} \mathrm{F}\left(23^{\circ} \mathrm{C}\right)$, the threshold of toxic effect was observed at $16 \mathrm{mg} / 1$ for 48 hours exposure (Bringmann and Kuhn, 1959). 
To evoke stimulation and movement of the water beetle, Laccophilus maculosis, a concentration of $\mathrm{LiCl}$ at $19,000 \mathrm{mg} / 1$ was required (Hodgson, 1951).

Low concentrations of $\mathrm{LiCl}$ are deleterious to the eggs of various aquatic organisms, retarding development and producing abnormalities. King (1953) demonstrated that concentrations of $848 \mathrm{mg} / 1$ were highly toxic to fly larvae, inhibiting emergence of offspring and retarding development of both larvae and pupae.

Cycropic embryos of the pond snail, Limnaea stagnalis, produced by the action of $\mathrm{Li}$ as $\mathrm{LiCl}$, were studied by Raven (1947). Li was found to cause the formation of a cyclopic eye, shortening of the cerebral commissure, other cnanges in the cerebral ganglion, and suppression of differentiation of most cell lines of the embryo of this species of snait. In related studies, Geilenkirchem (1952) stuaiea the effects of Li treatment of who? egg masses and isolated egg capsules in Limnaea stagnalis. Three groups of egg masses of Limnaea were treated with 0.01 percent of $\mathrm{LiCl}$ for one hour during second cleavage. Group I contained egg capsules treated within the je17y; Group I!, egg capsules isolated from the jelly; Group III, egg capsules isolated from the jelly, treated and washed. All eggs were subsequently cultured until hatching. Group I produced many more exogastrulae than either Group II or III. The number of head malformations was the same in all groups; however, the number of dead after six days was significantly greater in Group I than in Groups II or III. The authors concluded that the presence of the jelly during treatment did not influence the results; but its presence during rinsing resulted in the greater number of exogastrulae due to a delay in removal of $\mathrm{LiCl}$ from the eggs still in jelly during rinsing.

Ernanuelson (1971) studied the effects of lithium chloride on embryos of the polychaete, Ophryotrocha labronica. High concentrations strongly inhibited development in cleavage embryos and led to endodermā 7 protrusion; wneress moderate concentrations permitted development of larvae, although with characteristic disturbance as a consequence. Ultrastructure analyses of embryos revealed changes mariffest in 24 hours, i.e., of lipid droplets and yolk granules, the latter being ruptured and the contents dispersed to an extent far surpassing that at normal development.

Farinella-Ferruzza (1952) produced similar results in exposures of eggs of Ascidia malaca to $\mathrm{LiCl}$ at a concentration of C.8 percent and eggs of Phallusia mamillata at concentrations of 1.0, 0.8 , and 0.5 percent. In both species, eggs fertilized in LiCl developed with abnormalities, and development beyond gastrulation was gecerally arrested. However, eggs exposed to $\mathrm{LiCl}$, washed, and then fertilized in normal sea water developed without gross abnormality. Sensitivity to $\mathrm{LiCl}$ diminished with development, as determined for the unfertilized egg, the 2-blastomere stage, and the 64-blastomere stage. Witn strong concentrations (18\%), and in stages of precocious development (undivided egg, 2-biastomere stage) exogastrulas were obtained; whale with weaker concentrations $(0.8$ and $0.5 \%)$ and in later stages, defective larvae were obtained. Abnormatities observed in surviving larvae included deleted palps, sense organs, cerebral vesicles, and reduced or deleted tails. The author concluded that the mechanism of action of $\mathrm{LiCl}$ was not due to its affect on sperm; rather, in the physiochemical modification of the ovular plasma that always follows fertilization. The $L i$ ions are incorporated in the plasma molecular structure such that their influence is exercised throughout development. 
At 3 concentration of $3750 \mathrm{mg} / \mathrm{l}$, lithium chloride in distilled water was lethal to goldfish in 22 to 27 hours (Ellis, 1937). For adult small freshwater fish, the 24 hour lethal concentration was founa to be $2600 \mathrm{mc} / 1$ (Doudoroff and Katz, 1953). In other studies, lithium chloride at concentrations between 1950 and $3770 \mathrm{mg} / 1$ killed freshwater fish in 24 hours or sooner at warmer temperatures. Meinck, at al., (1956) reported that $100 \mathrm{mg} / 1$ of $\mathrm{LiCl}$ is toxic, but $33 \mathrm{mg} / 1$ is harmless to fish.

The lethal dose in 48 hours in the fish, Tinca vulgaris, for litnium fluoride was reported as $220,000 \mathrm{mg} / 1$ (Arena, 1963). However, Angelovic, et al. (1961) indiceted the median tclerance limit for $50 \%$ mortality $(T L m)$ for trout in soft water was $2.3-7.3 \mathrm{mg} / 1$ at $65^{\circ} \mathrm{F}\left(18^{\circ} \mathrm{C}\right), 2.6$ to $6.0 \mathrm{mg} / 1$ at $55^{\circ} \mathrm{F}\left(13^{\circ} \mathrm{C}\right)$, and 5.9 to $7.5 \mathrm{mg} / 1$ at $45^{\circ} \mathrm{F}\left(7.5^{\circ} \mathrm{C}\right)$. Neuhold, et al. (1960) repcrted the TLm for carp exposed to sodium fluoride was 75 to $91 \mathrm{mg} / 1$. Delays in hatching and reduction in hatching percentage occurred in trout embryos exposed to $1.5 \mathrm{mg} / 1$ fluoride (Ellis, 1946).

\subsubsection{Human Effects}

hibbard (1934) recommended that lithium in water for drinking and cooking purposes should not exceed $5 \mathrm{mg} / \mathrm{l}$. In man, the kidneys seein tc be rne site of toxic action of Li (Arena, 1963). The recommended level for fluoride in domestic water supplies is 0.7 to $1.2 \mathrm{mg} / 1$ (Mckee and Wolf, 1963).

\subsubsection{Conclusions}

Lithium released to the environment either during the mining cycle, from power plant operation, or accident, may be in the form of a number of compound types varying in solubility and affinity for biological organisms. From available data, toxicity would appear to vary according to solubility and possibly to $\mathrm{pH}$ shift.

Where comparative data are presented, animal forms are genera $7 y_{y}$ more susceptible than plant forms; the embryonic and juvenile life stages demonstrate greater sensitivity than the adult animal.

From the literature review, it is eviderst that the existing data base is incomplete and often contradictory, and in general, is of questionable value for the prediction and assessment of ultimate impact. The lack of information on source terms, in particular, complicates this problem.

However, assuming that the principal compound types released to the environment would include 1ithium fluoride $(L i F)$ an3 lithium oxide $\left(\mathrm{Li}_{2} \mathrm{O}\right)$, the following tentative conclusions could be reacned:

- In terrestrial habitats, toxicity tc plant communities could result from both root. absorption and foliar uptake. Toxicity would deoend upon solubility of the compound type; and in ground deposition, would be affected by soil pH. In acid soils, Li and its compounds wolild be present in more soluble forms, thus increasing absorption and toxicity. If deposited as the fluoride, concentration above soil equilibrium levels could result. In alkaline soils, however, most Li would be in an insoluble forn firmly bound by ?ime and clay. Toxicity would generally be greater in arid lands where soil moisture is lowest. Most agricultural crops appear to be sensitive to Li cr its compounds. Toxicity to animal forms including man could possibly result directly from contamination of drinking wster supplies, or from contaminated food stuffs. 
- In aquatic habitats, toxicity would vary with $\mathrm{pH}$. Freshwater hanitats would likely be more vulnerable than estuarine or marine habitats. In general, early life stages would be more sensitive than adult forms.

\subsubsection{Future Research Needs}

For both acute and chronic type exposures, concentration factors and turnover rates in the various compartments of both terrestrial and aquatic ecosystems must be determined. The potential for biomagnification must also be defined.

Longer term or chronic tests extending over the entire life cycle of selected test organisns should be used to determine the highest safe concentration of $\mathrm{Li}$ at which no adverse biological effects are observed. Data derived from these studies should be used to develop application factors that facilitate estimation of safe concentrations of $\mathbf{L i}$ from short-term acute tests. Subiethal stress in development, growth, feeding, and salient biochemical processes should be assessed to permit rapid detection of responses to $L i$ at stressing levels as low as those found by chronic tests to be biologicaily safe.

\subsection{Biological Effects of Sodium and Potassium}

Fusion power plants require a heat exchange system capable of handling large quantities of heat. The alkali metals sodium $(\mathrm{Na})$ and potassium $(\mathrm{K})$ are prime candidates for heat transfer media in these systems. They are extremely soft metals, lustrous and silvery in color and very light. Their high specific heat and the broad range of temperatures at which they maintain a liquid state make $\mathrm{Na}$ and $\mathrm{K}$ ideally suited for a heat transfer medium. The very remote possibility of a massive liquid metal fire or explosion breaching the reactor walls could result in substantial releases of $\mathrm{Na}$ and $\mathrm{K}$ compounds which may settle out to the ground or dissolve in nearby water bodies.

\section{2.? Sodium and Potassium and Their Compounds}

These similar metals are very reactive and do not occur naturally in the metal state. Several generalizations car: be made about their chemistry before examining each metal on an individual basis. These alkali metals will burn and produce potentially toxic oxides when exposed to air. The derivatives will dissociate in water to form a caustic hydroxide solution.

These exothermic reactions are summarized in the following equations (letting $A=$ alkali metal):

- Metal reacticns
1) $4 \mathrm{~A}+\mathrm{O}_{2} \longrightarrow 2 \mathrm{~A}_{2} \mathrm{O}$
Oxide
2) $2 \mathrm{~A}+\mathrm{O}_{2} \longrightarrow \mathrm{A}_{2} \mathrm{O} 2$
Peroxide
3) $\mathrm{K}+\mathrm{O}_{2} \longrightarrow \mathrm{KO}_{2}$
Superoxide, pctassium only

- Alkali oxide reactions

1) $\mathrm{H}_{2} \mathrm{O}_{2}+\mathrm{H}_{2} \mathrm{O} \longrightarrow \mathrm{HO}_{2}^{-}+\mathrm{OH}^{-}+2 \mathrm{~A}^{+}$

2) $\mathrm{HO}_{2}^{-}+\mathrm{H}_{2} \mathrm{O} \longrightarrow \mathrm{H}_{2} \mathrm{O}_{2}+\mathrm{OH}^{-}$ 
Alkali metals incur a vigorous reaction when mixed with water. This reaction liberates hydrogen gas which can be ignited solely by the exothermic heat of the reaction:

$$
2 \mathrm{~A}+\mathrm{H}_{2} \mathrm{O} \longrightarrow 2 \mathrm{AOH}+\mathrm{H}_{2} \uparrow+\Delta
$$

In the event of a massive liquid metal fire breaching the reactor walls, it is likely that a caustic mist or alkali oxide aerosol would be generated. The dispersal of such an aerosol would depend upon existing meteorological conditions. Wind and precipitation would impose the most significant factors. Because the alkali metals eventually break down into hydroxides and alkali metal ions. environmental impact would occur as a result of 1) elevation of hydroxide ion concentration and the toxic effects associated with this shift, and 2) specific toxic effects of the metal ions.

\subsubsection{Qualitative and Quantitative Analyses}

Hydroxide lon Concentration. Hydroxide ion concentration may be determined by measuring the $\mathrm{pH}$ which is the logarithm of the reciprocal of the hydrogen ion concentration. A pH value of 7 indicates that in one liter of solution the concentration of hydrogen ions (and a1 so the hydroxide ions) is $1 \times 10^{-7} \mathrm{M}$ As the acidity decreases, the $\mathrm{pH}$ value increases. A solution of $\mathrm{pH}$ value greater than 7 is basic or alkaline.

The $\mathrm{pH}$ value can be measured electrometrically or colorimetrically (APHA, 1971). The electrometric method is more practical. In theory, a change of $59.1 \mathrm{mV}$ at $77^{\circ} \mathrm{F}\left(25^{\circ} \mathrm{C}\right)$ is indicative of $1 \mathrm{pH}$ unit change across glass electrodes. The $\mathrm{pH}$ values can be determined with an accuracy of 10.05 units. Generaliy, pH values are reported to the nearest tenth of a unit.

Sodium. Sodium ( $\mathrm{Na}$ ) may be determined at levels as low as $10 \mu \mathrm{g} / 1$ using flame photometry with the wave length set at $589 \mathrm{m \mu}$. Compensation must be made for interference from other ions, particularly potassium $(\mathrm{K})$ and calcium $(\mathrm{Ca})$. Magnesium $(\mathrm{Mg})$, chloride, sulfate, and bicarbonate ions also interfere when they occur in relatively large proportions. An unknown containing $19.9 \mathrm{mg} / 1 \mathrm{Na}$ was analyzed in 35 laboratories with a relative standard deviation of 17.3 percent and relative error of 4.0 percent when this method was employed (APHA, 1971).

A gravimetric method for determining $\mathrm{Na}$ is not as sensitive as the flame photometric approach sc it is employed only when flame photometry is unavailable or to check results of a photometric test. Tests by four laboratories yielded a relative standard deviation of 11.3 percent and a relative error of 0.5 percent for an unknown containing $19.9 \mathrm{mg} / 1 \mathrm{Na}$. This method is based upon the precipitation of $\mathrm{Na}$ as sodium zinc uranyl acetate hexahydrate by the addition of zinc uranyl acetate reagent. Compensation must be made for potentially interfering ions.

Potassium. Potassium ( $K$ ) may be determined at minimum levels of $0.1 \mathrm{mg} / 1$ by flame photometry. The procedure is similar to the procedure for $\mathrm{Na}$, only the wavelength setting is $768 \mathrm{~m} \mu$. Ion problems of $\mathrm{K}$ are similar to those of $\mathrm{Na}$, although the chemicai dynamics are somewhat different. Analysis of an unknown containing $3.1 \mathrm{mg} / 1 \mathrm{~K}$ by 33 laboratories demonstrated a relative standard error of 2.3 percent (APHA, 1971).

Colorimetric determination $\mathrm{c} f \mathrm{~K}$ is not as sensitive as flame photometry. Minimum concentrations of $5 \mathrm{mg} / 1$ are detectable, but this technique is not advised for levels below $10 \mathrm{mg} / 1$ (APHA, 1971). Estimated accuracy of this method is $t 0.5 \mathrm{mg} \mathrm{K}$. Interference from other ions is negligible except for ammonium ion which should not be present at all. 


\subsubsection{Elevation of Hydroxide Ion Concentration and Toxic Effects}

\subsubsection{Terrestrial Effects}

Although pit is used extensively to appraise soil conditions, very little research has been directed at assessing its independent effect. This neglect may be attributed to difficulties in isolating the sole effect of $\mathrm{pH}$ from other chemical factors of the soil. However, some general conclusions can be made about $\mathrm{pH}$ and soil plant relationships.

Plant ecologists and physiologists generally assume that alkaline pH values exceeding 8.6 may be detrimental to plants, although $\mathrm{pH}$ tolerances are observed in excess of this value.

Shields, et a 1. (1964) reported that blue-green algae growin sol?s with pHs ranging from 8.6 to 10.0. Gisticalis spicata (salt grass) has been recorded by Fairchild and Wilson (1967) as growing on soil with a pH value of 9.9. These values are indicative of upper bounds observed in natural communities of very salt resistant biomes. Variation of $\mathrm{pH}$ tolerance may be observed on both intraspecific and interspecific levels.

Alkaiine pH regimes impart a corrosive effect which increases as alkatinity rises. The hydrolysis of $\mathrm{Na}$ in sodic soils ( $\mathrm{pH}>$ 8.5) imparts a caustic effect (Daubenmire, 1967). This condition is detrimental tc roots, soil humus, and associated soil microflora.

In the event of a massive spill, the resulting oxides and hydroxides wouid likely exert a devastating corrosive effect upon the soil and its associated biota. Mist or vapors resulting from such an incident could attain a theoretical pH value of 74.0. However, caustic reactions due to fallout generally would remain localized. Subseauent dilution, either natural or artifical, would weaken the reaction, but it would also disperse the pollutants downward into the rhizosphere and outward over a greater area. The caustic magnitude of this situation would be dependent upon many soil factors. Existing pH and buffering capacity of the soil couid exert a moderating effect upon the reaction. Other factors such as soil structure, permeability, soil moisture, amount of fallout and subsequent application of water to the soil also would determine the overall effect.

Caustic effects of corrosive aerosols or mists would vary according to plant species, Initial injury wolild occur to soft structures such as leaves, fruits and flowers. The bark of trees and shrubs would afford greater protection than the stems of most herbaceous plants. Whereas smaller herbaceous plants could be destroyed, woody plants might endure the initial stress over a season and eventually recover. tiowever, the plants susceptibility to disease and resistance to other environmental stresses would be diminished. Diffusion of the caustic components into the soil could impart an injurious affect on the soot structure of plants.

Sodium or potassium oxide or hydroxide fallout would prove detrimental to all forms of animal life it contacts. Alkali aerosols could cause severe damage to the eyes and moist pulmonary membranes, Extended contact with even dilute solutions would exert a corrosive effect. Smaller organisms would be affected more adverseiy than larger organisms but all would be more susceptibie to disease, predation and other environmental stress.

\subsubsection{Aquatic Effects}

Detrimental effects associated with alkaine shifts in aquatic systems are usually attributed to the toxicity of the associated cations, or organic and poorly dissociated inorganic bases. 
Potassium ( $\mathrm{Y}$ ) and sodium ( $\mathrm{Na}$ ) are highly dissociable cations and are generaliy nontoxic at $\mathrm{pH}$ levels iess than 3.0. In contrast, ammonium hydroxide exerts a marked toxic effect at concentrations with lower associated $\mathrm{pH}$ values (Aquatic Life Advisory Committee of the Ohio River Va? ?ey Sanitation Commission, 1955).

While righiy specific forms of aquatic vegetation have been observed at radical $\mathrm{pH}$ values, most aquatic plants survive within the range of 7.0 to 9.2 (NAS-NAE, 1972). Aphanizomenon flos-aquae (L.), a blue-green algae, was grown over a $\mathrm{pH}$ range of 5.0 to 11.0 with optimal growth recorded at 7.5 (Gentile and Maloney, 1969). Mckee and Wolf (1963) indicated thst a pH range of 7.5 to 8.4 is acceptabie for most aquatic plant growth.

Photosynthetic activity is respcnsible for large diurnal pH fluctuations in lentic habitats (still waters). Variations of $3.4 \mathrm{pH}$ units have been reported in dense beds of Potomogeton capense, and 1.5 units in colonies of Scenedesmus spp. and Microcystis spp.

For arimal forms, Mckee and Wolf (1963) report a range of 5.0 to 9.5 as tolerable for most species, with maximum productivity attained over the more restricted range of 6.5 to 8.2 . However, toxic $\mathrm{pH}$ ranges vary according to both the species and the ecotype.

Davis and Ozburn (1969) have recorded that the Cladoceran, Daphnia pulex is tolerant to a range of $\mathrm{pH}$ from 4.2-10.4; but parthenogenic reproduction was observed only within the range of 7.0 to 5.5. O'Brien and DeNoyelles (1972) reported the lethal threshoid for Cenodaphnia reticulata to be 10.8, and 100 percent mortality at 11.2. Jones (1941) demonstrated a marked decrease in survival of the flatworm, Polycel is nigra over a pH range of 9.6 to 11.6. Optimum pH range for 20 genera of caddisflies was 7.5 to 9.6 (Rctack, 1963). Curry (1962) recorded a range of 4.0 to 9.1 as sustaining survival of 80 species of midge larvae. It was also reported that a pH of 12.0 is the upper tolerance level for caddisflies and a pt: of 11.3 is the upper tolerance level for both stoneflies and dragonflies (NAS-NAE, 1972).

Using sodium hydroxide to adjust pH, Jones (1948) found that the stickleback, Gasterosteus spp. reacted distressfully at $\mathrm{pH}$ values of 11.4. Alkaline limits of rainbow trout have been recorded at 9.8, while goldfish, largemouth bass and bluegiils tolerated values at i0.4-10.5 (Jones, 1964). Jordan and Lloyd (1946) found that trout acclimated to more alkaline waters were subsequently more tolerant to increased levels of alkalinity up to a $\mathrm{pH}$ of 10.1.

Alkaline $\mathrm{pH}$ also has a deleterious influence on trout eggs and larvae (Krishna, 1953). Trout eggs exposed to alkaline mediums at 9.0 and above exhibited endosmosis, whitening $\mathrm{c} f$ the yolk, and apparent reduction of metabolism. Day old larvae exhibited 100 percent mortality at $\mathrm{pH}$ ranges of 8.0-9.0. Fertilized embryos were found to be more resistant to alkaline stress than eyed embryos or day old larvae.

Weib, et al. (1934) observed that fish required higher concentraticns of dissolved oxygen in relation to increasing alkalinity. Eight species of fish were stressed by varying $\mathrm{pH}$ levels and dissolved oxygen regimes. At lethal alkalinities, more dissolved oxygen remained in the water than at ncnlethal alkalinities. By altering initial dissoived oxygen concentrations, Wiebe then demonstrated an increased oxygen requirement in alkaline stressed fish.

Cairns, et al. (1970) attributed a decrease in dissolved oxygen in conjunction with increased alkalinity as a major cause of fish death as a result of the Clinch River fiy ash spill. 


\subsubsection{Specific Ion Effects}

Terrestriai Effects. Seifriz (1949) found that in silime molds coxicity to monovalent alkal: metal ions increased in the order of $\mathrm{Li}^{+}>\mathrm{Na}^{+}>\mathrm{K}^{+}>\mathrm{Rb}^{\mathrm{t}}$, while toxicity tc divalent alkaii setal ions increased in the order of $\mathrm{Ca}^{++}>\mathrm{Mg}^{++}>\mathrm{Sr}^{++}>\mathrm{Br}^{++}$. Divalent ions were found to be most toxic. Seifriz (1949) suggested that toxicity was related to relative permeability and hydration properties of the ion. Strogonov (1964) ratec $\mathrm{K}$ as the most permeable of the ccmmon ions associated with soil plant dynamics indicating that $\mathrm{K}$ may be more toxic than $\mathrm{Na}$ at equivalent concentrations. Meiri and Poljakoff-Mayber (1970) reported that isosmotic concentrations of sodium and potassium chloride in the growth substrate produced identical effects on bean plants.

Excessive amounts of Na do not generaily disturb the nutrient balance of plants. When exchangeable $\mathrm{Ca}$ levels are low, however, an increase in $\mathrm{Na}$, and presumably $\mathrm{K}$, will facilitate an ddditional deplecion of Ca. Calcium deficiency was shown detrimental for a variety of agricultural crops (Bernstein, 1964). LaHayne and Bernstein (1969) demonstrated that Ca levels lower than $1 \mathrm{mM} / 1$ can cause massive loading of $\mathrm{Na}$ in bean plents. No detrimental effects were observed when $\mathrm{Ca}$ concentration exceeded $1 \mathrm{~m} / \mathrm{M} / 1$.

Sodium-calcium imbalance is reported to cause red root disease in chrysanthemums (Kaabe, et al., 1966). This condition is identified by a reddening of the roots, loss of root tips and root hairs, and reduced growth.

Several other diseases of plants may also be attributed to Nö uptake and concentration. Avccaoo leaves exhibited Na scorch, a disorder characterized by marginal foliar bleaching and necrosis (Ayers, 1950). Similar symptoms appear on common cereal grains of the western U.S. (Treshow, 1970). Affected leaf tips turn white or greenish-white, the sheath twists, heaos energe imperfectly, and the seed may be deformed. Plants may be dwarfed and seed formation prevented. The presence of the alkali is tnought to inhibit the uptake of iron (Fe) and possibly other trace elements essential to the plant.

Plants would be a pathway for the potential detrimental effects of $\mathrm{Na}$ and $\mathrm{K}$ to animal forms. Alteration of habitat, principally by denuding the biome of plant life, would impose the worst case situatien in which animal forms are adversely affected. Vegetation is used by animals for both shelter and food.

Sodium is not considered a relatively toxic ion for most animal forms. Arimals would not be adversely affected if plants were not affected. Most animals are highly mobile and would likely avoid zones of deposited sodium or potassium oxides. However, those animals with soft and moist integuments such as amphibians could be more susceptible than mammals, birds, and reptiles.

Mckee and Woif (1963) reported that $2000 \mathrm{mg} / \mathrm{ha}$ was the toxic threshold Tor livestock in drinking water, and $7000 \mathrm{mg} / 1 \mathrm{Na}$ in drinking water was tcxic for chicks. There is little indication that biological magnification would pose a problem in food chains.

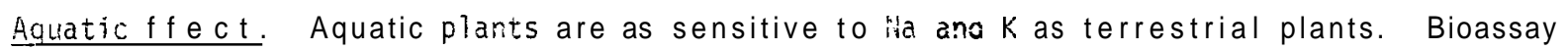
work has aimost exclusively dealt with animals, particularly fish. kork involving plants is directed toward nutritional deficiencies instead of toxic excesses. 
Cattail (Typha latifolia), an emergent macrophyte, was shown to have a minimal tolerance to osmotic stress imposed by Na salts (Choudhuri, 1968). The low tolerance to osmotic stress was particularly apparent in germination studies with sodium carbonate. Choudhuri attributed this to the corrosive nature associated with the carbonate ion.

The toxic effects of $\mathrm{K}$ and $\mathrm{Na}$ usually are overwhelmed by the corrosiveness associated with the hydroxide ion. However, the extent of this effect is moderated by the buffering capacity cf the aquatic biome. However, even in a buffered system, concentration of $\mathrm{Na}$ or $\mathrm{K}$ may be strong enough to exert a toxic affect on aquatic flora.

The cation exchange properties associated with terrestrial soils do not exist in aquatic systems. Calcium, $\mathrm{Mg}$, Na and $\mathrm{K}$ are so soluble that sufficient dissolved quantities of these cations are usually available to plants. The permeability of sediment structure may be affected, but most submergent aquatic plants have such reduced root systems that this effect may be negligible for estabiished organisms. However, decreased sediment permeability may adversely affect germination of submergent aquatic seeds.

Investigations of alkali metal toxicities in aquatic ecosystems employed the claudoceran, Daphnia magna, an important link in aquatic food chains. Toxicities associated with metals are viewed with emphasis upon the anionic components instead of the cation. Sodium has a relative toxicity less than $\mathrm{K}$ and Jones (1941) assumed the toxic effects of Na were equivalent to the anions of the least toxic salts, $\mathrm{NaCl}$.

Biesinger and Christensen (1972) found $\mathrm{Na}$ to be the least toxic of 21 metals. Chloride salts were used throughout their work so the possibility exists that the measured stress could be partially attributed to the chloride ion. $A n L_{50}$ for Daphnia magna was found at $1,480 \mathrm{mg} / 1 \mathrm{Na}$ and $97.0 \mathrm{mg} / 1 \mathrm{~K}$. Significant reduction in reproductive potential was observed at $680 \mathrm{mg} / 1 \mathrm{Na}$, and $53 \mathrm{mg} / 1 \mathrm{~K}$. The $\mathrm{pH}$ levels in Biesinger's work did not fluctuate more than 0.3 units, hence the effects may not be attributed to hydroxyl ion effects. Freeman and Fowler (1953) acknowledged the tendency of increased toxicity contributed by a change of $\mathrm{pH}$ from 8.2 to $9.3 \mathrm{in}$ conjunction with different combinations of sodium salts.

The review of Doudoroff and Katz (1953) on metal toxicity of fish agrees that $\mathrm{K}$ is more toxic than $\mathrm{Na}$. Toxic responses are cited for freshwater fish over the range of 50 to $400 \mathrm{ppm}$ for $\mathrm{K}$, and $500 \mathrm{ppm}$ to $2000 \mathrm{ppm}$ for $\mathrm{Na}$. The variation in toxic range may be attributed to the different salt forms, time of exposure, buffering capacity of the water and the species of fish tested. Mckee and Wolf (1971) cited toxicity leveis of $200 \mathrm{mg} / 1 \mathrm{~K}$ for Gammaridae, $700 \mathrm{mg} / 1 \mathrm{~K}$ for Chironomidae and $1000 \mathrm{mg} / 1 \mathrm{~K}$ for Trichoptera,

high concentrations of $\mathrm{Na}$ and/or $\mathrm{K}$ may inflict an osmotic stress upon aquatic crganisms. Invertebrates are particularly susceptible to this stress as their entire body surface is involved in absorption of water and solutes. Finley (1930) found that the degree of adaptability to saline media varied with the species of freshwater protozoan. Protozoans generally addpted to osmotic and toxic stress when changes were gradual. A few species were able to survive and reproduce when transferred directly to a saline medium. 


\subsubsection{Conclusions}

In considering the remote possibility of a severe liquid metal fire or explosion which could disperse a caustic alkali aerosol to both surrounding terrestrial and aquatic habitats, the impacts of such an occurrence are estimated in the following paragraphs. A dilution gradient would exist as the distance increased from the source of contamination, and presumably the intensity of biological response would similarly decrease. Also, the effects of such a contaminant or contaminants on a particular biome would vary according to inherent abiotic and biotic features.

Arid Land. Soil development is attributed to calcification in arid lands. Soils are highly aggregated due to the immobility of colloids and the high concentrations of $\mathrm{Ca}$ and $\mathrm{Mg}$. Vegetation is sparse and the humic content of the soil is negligible. Saline, saline-alkali and sodic soil conditions are usually associated with this biome.

These soil types would be particularly susceptible to alkaline stress. Low humus concentration and colloid characteristics would limit the buffering capacity of the soil. Dynamics of cation exchange would impose additional stress relative to alkaline reactions. The ecology of arid lands is extremely fragile. The biota are designed to cope with an area of natural environmental stresses. Arid lands not only would be the most drastically affected but, due to minimal precipitation, would require the longest natural recovery time.

Grassland. Calcification is the predominate soil forming process associated with grasslands. Precipitation, 10-30 inches annually, accounts for more plant growth, but is considered insufficient for trees. Irrigation practices have converted many arid lands into productive agricultural grass?ands thus, in some respects, the relaticnships associated with arid lands also apply to grasslands.

Grassland soils contain greater quantities of humus which increase the buffering capacity of the soil, alleviating the alkaline stress factor. Most native species of grass are adapted to low salinity and slight acidity to moderately alkaline $\mathrm{pH}(6.0-8.0)$.

Grassland organisms could possibly tolerate a greater insult of alkali metal related stress. Where the rhizosphere of established communities would extend 6 feet into the ground and surface root absorption would be reduced, the deeper unaffected roots could assume these functions. This would allow a quicker recovery of grassland areas.

Forest. At least 30 inches of precipitation is necessary for the growth of trees in a warm or cool climate.

Soil pH values are predominately acid (less than 7.0 ) resulting from the accumulation and decomposition of forest litter, mineral decay of parent materials and metabolism of soil organisms. An acid soil regime would tend to neutralize alkaline reactions derived from alkali metal contamination. A buffering effect would be derived from certain solid colloids and solutes.

The forest litter itself would retard the dissemination of harmful contaminants into the soil. Soi 1 contamination would eventually occur, but only after corrosive action consumed a major portion of the forestlitter. Complete destruction of the forest litter would expose the soil to both wind and water erosion. This would be an adverse impact since forest litter provides a habitat for many organisms, particularly insects, other invertebrates and microorganisms. 
Marshlands. A marshland is a link between two very broad habitats: terrestrial and aquatic. Marshlands may in fact exist between bodies of freshwater and the terrestrial biome or in association with the marine environs.

Because of a higher moisture content, dissociation of alkali oxides and hydroxides would be accelerated greatly and subsequent dissemination into the soil or sediments would be increased. Aerosol fallout would impart an instantaneous corrosive action on the moist surface. Proximity to an aquatic biome would facilitate dilution, although this effect would be moderated by the physical properties of the substrate.

The ecology of wetlands or marshlands would be extremely vulnerable to contamination from a liquid metal spill. Wetlands or marshlands often provide special habitats required for rare and endangered species of amphibians, reptiles and fish. Such sites are often breeding or wintering grounds for many species of waterfowl and water birds. Isolated populations of rare piants (ferns, venus fly trap) are also often associated with wetlands.

Freshwater Lentic Habitats. Lentic (stitl water) environments represent the most vulnerable of aquatic biomes. Outflow of most lakes and ponds is usually minimal and in some cases nonexistent. Percolation through the sediments would afford the only natural mechanism of removal or neutralization of these contaminants. The buffering capacity would vary and its relevance would be negligible in relation to a large spill. Detrimental conditions would persist for great lengths of time and would require artificial means to alleviate their effects. A reduction of productivity in lentic biomes would also effect the dynamics associated with terrestrial biomes as many organisms transcend both habitats. Rehabitation of dis urbed lentic environments would be slow for most endemic biota. Totally aquatic organisms may not be able to rehabitate without human assistance.

Lakes in temperate regions are usually stratified through the influence of thermoclines. Stratification may maintain elevated concentrations of contaminants in the epilimnion by restricting the dilution process. The epi7imnion is the most productive region of dimictic lakes; hence, any disturbances to this area would be of prime ecological significance.

Freshwater Rivers and Streams. Detrimental effects of contaminants can be distributed along the downstream route of a river or stream. Severity of this effect would be moderated as the contaminants move downstream and are subsequently diluted. The Clinch River fly ash spill (Cairns, et a1., 1970) exemplifies this process. Approximately 130 million gallons of caustic calcium hydroxide (pH 12.0-12.7) spilled into a tributary of the Clinch River. This amounted to approximately 40 percent of the daily flow. Bottom fauna were completely eliminated 3 to 4 miles downstream and a drastic reduction was noted as far as 77 miles downstream. Total mortality for all species of fish was reported for 66 miles below the spill. After 2 years, al1 endemic organisms had rehatitated the affected area immediately below the source of contamination; however, the population density was not as great as the unaffected population density above the source of contamination.

Estuarine and Coastal Marine Habitats. Buffering capacity of sea water is greater than most fresh waters; hence, both estuarine and coastal marine habitats will assimilate greater volumes of alkali contaminant without adverse effects. Organisms close to a source of contaminaticn would likely still be affected, but ultimate impact would not be severe. Biota inhabiting 
estuaries and coastal marine environs would tolerate often extreme variations in alkalinity and other water properties. The $\mathrm{pH}$ fluctuations of temperate estuaries often range between 6.5 and 9.5 .

\subsubsection{Future Research Needs}

Present research does not adequately deal with the environmental impact associated with liquid metal disasters. Of particular significance are the dynamics involved with the hydrolysis of alkali metal oxides in ecosystems and the fate of the alkali and hydroxide derivatives.

Further ecological investigations into sodic soil habitats and alkaline aquatic habitats would aid in delineating the explicit effects of these contaminants at their most tolerable biological extremes.

Bioassay work should be conducted for both acute and chronic effects on organisms of significant value to their respective ecosystems. Efforts should be made to assess both caustic hydroxide effects and specific ion effects independent of each other. Rates of turnover and removal by both natural and artificial means should be analyzed. Such an assessment would facilitate the development of reasonable monitoring programs associated with fusion power plants.

\subsection{Biological Effects of Beryllium}

Beryllium ( $\mathrm{Be}$ ) may be included in the fixed blanket structure in certain fusion reactor designs as a neutron multiplier. In the most severe accident estimated, a massive liquid metal fire or explosion could create sufficient pressure to breach reactor containment walls. This would result in the release of significant quantities of combustion products including oxides or hydroxides of the metal Be, dispersed as aerosols ultimately deposited on the ground or nearby water bodies. Significant releases of oxides of Be as aerosols could also occur during the mining, refining and fabrication of materials intended for fusion reactor use.

The entry of Be into the food chain with biomagnification could present a hazard to man. To assess and predict the effects of Be released to the environment, it is necessary to know how readily the metal is metabolized by biological organisms, and at what levels toxicity could be expected.

\subsubsection{Beryllium and Its Compounds}

Beryllium is an alkaline earth and forms a series of compounds resembling others of the magnesium family. Be forms the monoxide, Be0, when heated in air or oxygen $(0)$. BeO does not react with water and melts at $2500^{\circ}$. It forms the dioxide, $\mathrm{NaHBeO}_{2}$, in the presence of alkali hydroxide $(\mathrm{NaOH})$. The hydroxide, $\mathrm{Be}(\mathrm{OH})_{2}$, is insoluble in water but is amphoteric and dissolves $\mathrm{i} n$ both acids and alkalies. The salts of Be readily hydrolyze and form basic compounds.

\subsubsection{Qualitative and Quantitative Analysis}

Beryllium is most commonly determined by spectrophotometry (APHA, 1971). In principle, a small quantity of EDTA is added to the Be sample to prevent interference from moderate quantities of aluminum ( $\mathrm{A}$ ), cobalt ( $\mathrm{Co})$, copper $(\mathrm{Cu})$, iron ( $\mathrm{Fe})$, manganese $(\mathrm{Mn})$, nickel ( $\mathrm{Ni})$, titanium (Ta), zinc $(Z n)$, and zirconium $(Z r)$. An $A l$ buffer reagent is then added to form a Be lake and the color developed is measured at $515 \mathrm{mu}$. 
Development of a standard curve relationsinip is necessary. The unknown, distilled water blank, and Be standards are analyzed as nearly simultaneously as practical. The concentration of Be in the unknown is determined from the calculation:

$$
\mathrm{mg} / \mathrm{T} B \mathrm{e}=\frac{\mu \mathrm{g} B \mathrm{Be}}{\mathrm{ml} \text { sample }}
$$

The minimum detectable concentration for Be is $5 \mu \mathrm{g} / 1$. In an unknown sample furnished to 32 independent laboratories, Be in the presence of other interfering metals was determined with a relative standard deviation of 7 percent and a relative error of 12 percent (APHA, 1971).

\subsubsection{Behavior and Effects of Beryllium in the Environment}

\subsubsection{Terrestrial Effects}

Concentration and toxicity of $\mathrm{Be}$ was reported in a wide spectrum of organisms including plants, animals, and man.

Growth in length of squash roots, Cucurbita pepo, and Carthamus tinctorius, was inhabited 34 to 46 percent in $7.3 \times 10^{-6}$ to $7.3 \times 10^{-3}$ M Be sulfate (Hopkins, 1952). Growth of bush bear, Phaseolus vulaaris, was significantly inhibited when 10-day-old seedlings were transferred from sand culture to aerated nutrient solutions containing 0.5 to $1.0 \mathrm{mg} / 1$ Be (Rominey, et al., 1962 ). Roots turned brown within 5 days of exposure and failed to resume normal elongation. Stunting of plant foliage was apparent within 10 days of exposure, and abnormal flowering was observed at the highest concentrations of Be. Roots accumulated $\mathrm{Be}$ and leaves accumulated the highest concentrations. Small amounts accumulated in the bean fruits. In exerting its toxic action on the bush bean plant, increased Be concentrations decreased Ca content in roots and stems.

Phosphorous (P) content was slightly increased in stems, leaves, and fruits. Romney, et al. (1962) believed the inhibitory effects of Be on plart growth were centered in root tissues, and that Be may have inhibited normal functions of the plants phosphatase enzyme system. An inhibition of normal metabolism of inorganic $P$ which the plant attempted to overcome by increased $P$ uptake also may have accounted for increased $P$ concentrations at higher levels of Be. Beryllium did not appear to inhibit synthesis and function of chloroohyll.

Beryllium has produced sarcomas in rabbits, pulmonary cancer in rats and monkeys, and rickets and osteosclerosis in livestock (Vorwald, et a1., 1966).

\subsubsection{Human Effects}

Humans breathing aerosols containing Be were reported to contract bronchitis and pneumonitis, while direct skin contact with Be resulted in conjurictivitis, dermatitis, and ulceration (Vorwald, 1966).

Recommended trace element tolerances for continucusly used irrigation waters is $0.5 \mathrm{mg} / 1 \mathrm{for} \mathrm{Be}$ (National Technical Advisory Committee to the Secretary of the Interior, 1968). The U.S. Public Health Service drinking water standards limits Be to $0.1 \mathrm{mg} / \mathrm{l}$ (Breslin, 1966). The recomended allowable fume or dust concentration in air is $0.002 \mathrm{mg} / \mathrm{m}^{3}$ (Arena, 1963).

\subsubsection{Aquatic Effects}

Goldberg, et a1. (1971) reported that Be was concentrated 1000 times in marine plants and animals Beryllium apparently is toxic for a variety of aquatic organisms. 
Karlander and Krauss (1972) found that the alga Chorell a vannielii absorbed up to $44 \mathrm{mg}$ of Be per mg dry weight from a culture solution containing $10 \mathrm{mg} / 1$ of $\mathrm{Be}(\mathrm{OH})_{2}$. Maximum autotrophic growth rates were inhibited 10 to 20 percent by the addition of $100 \mathrm{mg} / 1$ Be to culture solutions.

From field experiments with Be, Karlander and Krauss (1972) concluded that knowledge of the pH of receiving waters was an important factor in determining the biological availability. In general, low $\mathrm{pH}(<7.0)$ enhanced the solubility of $\mathrm{Be}$, while the presence of $\mathrm{OH}$ - ions caused precipitation of Be. Karlander and Krauss (1972) also indicated that biological availability depended upon the relative amount of suspended material in receiving waters. Beryllium adhered to many surfaces, and most material not in solution attracted Be, and if in the hydroxide form, caused it to precipitate. Other materials such as phosphates were implicated in the precipitation of Be. However, Everest (1964) reported that some organic compounds, such as citric acid, chelated Be helping to maintain it in solution.

Toxicity tests indicated that 96 hour $L C_{50}$ for fathead minnow, Pimephales promelas, exposed to beryllium chloride, was $0.15 \mathrm{mg} / 1$ in soft water, and $15 \mathrm{mg} / 1$ for the same species in hard water (Tarzwell and Henderson, 1960). Jackim, et al. (1970) reported a 96 hour LC $_{50}$ of $31 \mathrm{mg} / 1$ for the mummichog, Fundulus heteroclitus, exposed to beryllium chloride.

The maximum concentration of Be acceptable in marine or estuarine waters should not exceed 0.01 of the 96 hour $L C_{50}$ value determined for a particular receiving water and using the most important sensitive species present as the test organism. Concentrations of Be in marine or estuarine waters in excess of $1.5 \mathrm{mg} / 1$ would be unacceptable.

\subsubsection{Conclusions}

Beryllium released to the environment during the mining cycle or reactor accident situation could be in the form of a number of compound types. Solubility and hence biological availability would vary with $\mathrm{pH}$, the presence of certain other inorganic and organic compounds, and the physiochemical forms of these compounds; i.e., ionic, colloidal, or particulate.

Beryllium toxicity was demonstrated in a variety of organisms including plants, animals, and man. Where comparative data is available, animals are generally as susceptible as plants. Evidence suggests that Be concentrates in both plant and animal forms with potential for biomagnification in food chains leading to man.

From the literature review, it is evident that the existing data base is fragmentary, and is of questionable value for prediction and ultimate assessment of impacts. The lack of information on specific compound types released to the environment during the mining cycle or reactor accident further complicates this problem. However, assuming that the principal compound types of Be released to the environment are oxides or hydroxides, which are relatively insoluble, and the levels released exceed maximum acceptable concentrations, the following conclusions are reached.

In terrestrial habitats, toxicity to plant communities would initally be minimal, but could increase with time after dispersal due to microbial interaction in low pH soils to form more soluble, biologically available compound types. In regions where acid rains occur, solubility of these compounds would likely be enhanced with the opportunity for more immediate adverse effects. Toxicity to animal forms including man could result directly from skin contact or - inhalation, or from ingestion of contaminated foodstuffs. Ingestion of domestic herbivores, dairy products, and game animals constitute other potential pathways to man. Crops such as tobacco might also collect these potentially toxic compounds and constitute yet another pathway to man through smoking. 
In aquatic habitats, toxicity would vary with pH. It is likely that freshwater environments would be more vulnerable than estuarine or marine environments. Microbial interaction in sediments could play an important role in rendering the relatively insoluble oxides and hydroxides more soluble making them more available for direct toxic effect. However, indirect toxic effects could be more important, in that filter feeding organisms (molluscs, insect larvae, crustaceans, and fish) would ingest significant quantities of toxic metal absorbed to foodstuffs. This could be true also for detrital feeders such as oligochaete and polychaeta worms, insect larvae, and crustacea. Ingestion of fish and shell fish constitute potential pathways to man.

\subsubsection{Future Research Needs}

For both acute and chronic type exposures, concentration factors and turnover rates in the various compartments of both terrestrial and aquatic ecosystems must be determined. The potential for biomagnification must also be defined.

Longer term or chronic tests extending over the entire life cycle of selected test organisms should be used to determine the highest safe concentration of Be at which no adverse biological effects are observed. Data derived from these studies should be used to develop application factors that facilitate estimation of safe concentrations of Be from short-term acute tests.

Assessment of sublethal stress, i.e., development, growth, feeding, and salient physiological and biochemical processes, should be conducted to permit rapid detection of responses to Be at stressing levels as low as those found by chronic tests to be biologically safe.

\subsection{Salt Drift from Cooling Towers}

The pctential exists for the accumulation of salts in the environment surrounding nuclear power plants that employ cooling towers to dissipate waste heat. The quantities of salts associated with drift depends largely on the quality of makeup water. Additional salts are contributed by chemical additives and corrosion products associated with the cooling cycle. Dispersal depends upon tower height and prevailing meteorological conditions with ultimate deposition governed by wind direction and velocity.

\subsubsection{Behavior and Effects of Salt Drift in the Environment}

\subsubsection{Terrestrial Effects}

The primary impacts of salt drift deposition in terrestrial habitats will effect 1) the bare soil, such as newly plowed or fallow fields, and 2) vegetative surfaces of various kinds of crop plants, natural grass, shrub, and tree communities.

Most data on the effects of salt accumulation in soil in relation to piant growth are available from research on irrigated agricultural practices. Effects on plant growth depend on the quantity and chemical composition of salts in the source water. The quantity of salts may vary, ranging from $70 \mathrm{ppm}$ in the Columbia River water at Wenatchee, Washington, to $2300 \mathrm{ppm}$ in the Pecos River at Carlsbad, New Mexico. An acre-foot of Colorado River water may add 2000 pounds of soluble salts to an acre of crop land in the Imperial Valley of California. However crops are still grown successfully if sufficient water is available and subsurface drainage for excess water is provided. Furthermore, the adverse effects of soluble salts on crop lands depends on the total concentration of sodium, and the proportion of sodium to calcium and magnesium, the concentration of bicarbonate, and the presence of such toxic elements as boron. 
Natural plant communities are also affected by these factors, but also are probably vulnerable to deposition of soluble salts on the surface soil which may serve to decrease seed germination and seedling development. It is not likely, then, that deeply rooted perennial plants would be directly affected by salt deposition in surface soils, but may fail to reproduce because of unfavorable conditions associated with chemical changes in surface soils.

Studies of long-term drift deposition patterns at Oak Ridge, Tennessee (Taylor et al., 1975), disclosed high concentrations of both chromium and zinc near cooling towers, but adverse effects on native species were not observed except in leaf size reductions in tobacco plants, an unusually sensitive species.

The retention of deposited salts on natural grasses, shrubs, and tree communities is temporary since most plants experience a yearly senescence, and dead plant parts drop to the ground.

The ultimate repository for salt deposition is the soil. Impact will vary according to the prevailing ecosystem, i.e., desert, grassland or forest:

- In arid regions, the rate of evapotranspiration is high relative to precipitation; salt deposition will contribute to accumulation of salinity in soils, with the potential for marked change in vegetation.

- In grassland, the rate of evapotranspiration is usually approximately equal to precipitation; there still exists potential for accumulation of salinity in soils. When this occurs, a shift from low salt tolerant species to high salt tolerant species may result.

- In deciduous forests, the rate of evapotranspiration is generally exceeded by precipitation with the result that salt deposited from cooling tower drift is diluted and does not accumulate; adverse impact on such forest habitats is not likeiy to occur. However, in forests located in more arid regions, the evapotranspiration rate again approximates precipitation with the potential for salt accumulation, and thus adverse impact.

\subsubsection{Animals}

Cooling tower drift may contain trace quantities of arsenic, cadmium, lead, chromium and mercury, and also biocides. If threshold limits are exceeded, toxicity to animals as well as plants niay result. Deposition of drift on foliage is the principal route by which such materials may potentially affect animal forms; however, direct skin contact and inhalation constitute other important routes. Man is potentially affected by eating contaminated vegetables, doniesticated animals, dairy products, and game animals. Crops such as tobacco may also collect drift and affect man through smoking. Although the magnitude of impacts to animals cannot be accurately assessed from the available dátá base, it does not appear to be serious provided emission controls are maintained.

\subsubsection{Aquatic Effects}

Impacts on aquatic species are not usually associated with salt drift, but are more closely related to the direct discharge of cooling tower blowdown to aquatic habitats. However, some measure of impact may result from deposition of salt drift on freshwater marshes.

\subsubsection{Conclusions}

Salt deposition will contribute significantly to the accumulation of salinity in soils of arid regions, and to some degree in grasslands, with potential for adverse impact or vegetation. Salt from cooling towers will not likely accumulate in forested regions. Cooling tower salt 
drift may contain trace quantities of arsenic, cadmium, lead, chromium, and mercury, and $\mathbf{i f}$ threshold limits are exceeded, toxicity to animals as well as plants could result. Man may be affected by eating contaminated vegetables, domesticated animals, dairy products, and game animals. Crops such as tobacco may also collect salt drift and affect man through smoking. Impacts on aquatic habitats are usually not associated with cooling tower drift, although some measure of impact may result from deposition on freshwater marshland.

\subsubsection{Future Research Needs}

Salt drift from cooling towers is a problem for both fission and fusion designs; and site specific conditions will weigh heavily on ultimate assessment impact. Future research needs include provisions to better characterize the heavy metal constitutents and other compounds comprising salt drift, as well as assessing their relative toxicities to indigenous flora and fauna. Tests under site specific conditions and utilizing indigenous species need to be conducted before the significance of impact may be predicted. Finally, atmospheric dispersed of salt drift on a site-by-site basis must be studied and modeled.

\subsection{Routine Releases to Water}

As in the case of salt drift, adverse effects to aquatic species from chemical releases may occur in the discharge of both fission and fusion power plant designs. Such releases are manifested as a community response involving detectable changes in the total number of species and individuals comprising a species. This may result because of temporary, intermittent, or continuous release of toxic chemicals (biocides, corrosion inhibitors, dissolution products). The potential impact is reduced abundance or total loss of one or more species, and sometimes the substitution of undesired species.

\subsection{1, Effects of Routine Chemical Releases in the Aquatic Environment}

All aquatic organisms are potentially susceptible as they are in direct contact with the toxic materials in solution or suspension. The toxic material enters aquatic organisms through their integument, membranes, gills, or mouth. Mortality may be direct, or indirect when small quantities accumulate within the flesh of affected organisms. Accumulated materials may cause reduced fecundity, lowered stamina, or stunting of growth. Organisms low on the food chain may be destroyed, so that valued species at higher levels find little forage and may be eliminated or displaced. However, aquatic organisms vary widely in their tolerance to toxic chemicals. Also susceptibility depends upon the life stage of the organism, and as well, the concentration of the toxicant, and the abiotic features of the habitat.

Cooling water is used routinely to dispose of small quantities of chlorine, alkaline hydroxides, copper, nickel, iron, zinc, chromium, and boron, by means of dilution, dispersion, and reduction. Potentially toxic materials may also reach the aquatic environment by liquid seepage from onshore disposal basins, control of fouling organisms in cooling systems, and concentration of chemicals in blowdown from cooling towers.

However, chemicals normally used in the routine operation of power plants are well characterized, and if chemical releases are controlled at the plant, their actual impact on aquatic organisms will be minimal. 


\subsubsection{Conclusions}

Adverse effects to aquatic organisms from routine chemical releases are likely to occur in fusion power plants as they occur currently in discharges from fission designs. All aquatic organisms are potentially susceptible; mortality may be direct, or indirect when small quantities accumulate within the flesh of affected organisms. Cooling water discharges are used routinely to dispose of small quantities of chlorine, alkaline hydroxides, copper, nickel, iron, zinc, chromium, and boron, all potentially toxic compounds and elements. However, such constituents are usually well characterized, and if releases are controlled at each plant site, their actual impact on aquatic organisms will be minimal.

\subsubsection{Future Research Needs}

Chemical releases from nuclear plants are encountered in both fusion and fission reactor designs; and site specific conditions will weigh heavily on ultimate assessment of impact. Then, on a site specific basis, research needs include the provisions to determine the quality of cooling and receiving water to detect the presence and background levels of important chemical constituents; to determine by laboratory and field bioassay the potential acute and chronic effects of altered water quality and chemical discharges on susceptible biota; and to determine the potential for accumulation and biomagnification of discharged chemicals in susceptible biota. 


\section{Biological Effects of Activation Products}

Steiner, D. and A. P. Fraas, Preliminary Observations on the Radiological Implications of Fusion Power, Nuclear Safety 13, 353, 1972.

University of Wisconsin Feasibility Study Group, G. L. Kulcinoky (Director), UWMAK-I, A Wisconsin Toroidal Fusion Reactor Design, UWFDM-68, University of Wisconsin, 1973.

Young, J. R., B. F. Gore, D. D. Mahlum, J. A. Strand, R. C. Thompson, and J. K Soldat, Information Requirements for Controlled Thernionuclear Reactor Environmental Statements, BNWL-1883, Battelle-Pacific Northwest Laboratories, Richland, WA 1975.

Vlamis, J. and G. A. Pearson, Absorption of Radioactive Zirconium and Niobium by Plant Roots from Soils and Its Theoretical Significance, Science 111: 112-113, 1950.

Shroeder, H. A., M. Mitchener, J. J. Balassa, M. Kanisawa, and A. Nason, Zirconium, Niobium, Antimony and Fluorine in Mice: J. Nutrition 95: 95-101, 1968.

Furchner, J. E. and G. A. Drake, Comparative Metabolism of Radionuclides in Mammals. VI. Retention of $95 \mathrm{Nb}$ in the Mouse, Rat, Monkey and Dog, Health Physics 21: 173-180, 1971.

Polikarpov, G. G., Radioecology of Aquatic Organisms, Reinhold Book Division, New York, p 314, 1966.

Eisenbud, M., Environmental Radioactivity, 2nd Edition, Academic Press, New York, p 542, 1973.

National Academy of Science, Medical and Biologic Effects of Environmental Pollutants Vanadium, National Academy of Sciences, Washington, 0i, p 117, 1974.

Welch, R. M., W. D. Huffman, Ir., The Growth of Lettuce, Lactuca sativa (L.) and Tomato, Lycopersion esculentum Mill, Plants in Nutrient Solutions Low in Vanadium, Plant Physiol. 52: $183-185,1973$.

Mckee, J. E. and H. H. Wolf (Eds.), Water Quality Criteria, 2nd Edition, Resources Control Board, Publ. No. 3-A, 1971.

Swinehart, J. H., W. R. Briggs, D. J. Halko, and N. C. Schroeder, The Vanadium and Selected Metal Contents of Some Ascidians, Biol. Bull. 146: 302-312, 1974.

Tarzwell, C. M. and C. Henderson, The Toxicity of Some of the Less Common Metals to Fishes, Trans., Seminar on Sanitary Engineering Aspects of the Atomic Energy Industry, Robert A. Taft San. Engrg. Center, TID-7517, 1956.

Cate, R. B. and A. P. Sukhai, A Study of Aluminum in Rice Soils, Soil Sci. 98: 85-93, 1964.

Pugh, N. J., Treatment of Doubtful Waters for Public Supplies, The Surveyor 104, 263, 1945; Water Pollution_ Abs. 18, 1945.

Anon., Ohio River Valley Water Sanitation Commission, Subcommittee on Toxicities, Metal Finishing Industries Action Committee, Report No. 3, 1950.

Browing, E., Toxicity of Industrial Metals, Butterworths, London, England, 1961.

Bringmann, G. and R. Kuhn, The Toxic Effects of Waste Water on Aquatic Bacteria, Algae, and Small Crustaceans, Gesundneits - Ing. 80, 115, 1959.

Anderson, B. G., The Apparent Thresholds of Toxicity of Daphnia magna for Chlorides of Various Metals when Added to Lake Erie Water, Trans. Amer. Fish Soc. 78, 96, 1948; Water Pollution Abs. 23, 1950.

Doudoroff, P. and M. Katz, Critical Review of Literature on the Toxicity of industrial Wastes and Their Components to Fish. II. The Metals, as Salts, Sewage and Industrial Wastes 25, 809, 1953.

Hewitt, E. J., Metal Relationships in Plant Nutrition. . Effects of Some Metal Toxicities on Sugar Beets, Jour. Exp. Botany 4: 59, 1953. 
Menze1, R. G., Soil-Plant Relationships of Radioactive Elements, Health Physics 11: 1325, 1965.

Sax, N. I - Dangerous Properties of Industrial Materials, Reinhold Publishing Corp., New York, 1963.

Klintworth, H., Quality Requirements of Water for Agriculture, So. Afr. Ind. Chemist. 6: 117, 1952.

Sedova, G. P., On the Question of Sanitary Assessment of Soil Irrigation with Sewage Containing Chromium, Gigiena i Sanit 23: 6-15, 1958.

Byerrum, R. U., Some Studies on the Chronic Toxicity of Cadmium and Hexavalent Chromium in Drinking Water, Proc. 15th Ind. Waste Conf., Purdue University, 1960.

Mackenzie, R. D., C. A. Hoppert, and R. U. Byerrum, Studies of Cadmium and Chromium Solubility and Toxicity, Jour. A.W.W.A. 49, 1310, 1957.

MacKenzie, R. D., R. U. Byerrum, C. F. Decker, C. A. Hoppert, and R. F. Langham, Chronic Toxicity Studies. II. Hexavalent and Trivalent Chromium Administered in Drinking Water to Rats, AMA Archives Ind. Health 18, 32, 1958.

Decker, C. F., C. A. Hoppert, and R. U. Byerrum, Report on Toxicity Studies of Cadmium and Chromium, Jour. A.W.W.A. 48, 1279, 1959.

Decker, L. E., R. U. Byerrum, C. F. Decker, C. A. Hoppert, and R. F. Langham, Chronic Toxicity Studies. II. Hexavalent and Trivalent Chromium Administered in Drinking Water to Rats, AMA Archives Ind. Health 18, 232, 1958.

Anwar, R. A., C. A. Hoppert, and R. U. Byerrum, Toxicity Studies on Cadmium and Hexavalent Chromium, Water and Sewage Works 107, 465, 1960.

Anderson, B. G., The Toxicity Thresholds of Various Substances Found in Industrial Wastes as Uetermined by tne Use of Ũaphnia magna, Sewage Works Jour. 16, 1156, 1944.

Olson, P. A., Comparative Toxicity of Cr (VI) and Cr (III) in Salmon, Hanford Biology Research Annual Report for 1957, Office of Tech. Services, U.S. Department of Commerce, Washington, DC, 1958.

Meinck, F., H. Stooff, and H. Kohlschütter, Industrial Waste Waters, 2nd Edition, Gustav Fisher Verlag, Stuttgart 536, 48, D. M., 1956.

Ely, R. E., K. M. Dunn, and C. F. Huffman, Cobalt Toxicity in Calves Resulting from High Oral Administration, Jour. Animal Sci. 1, 239, 1948.

Turk, J. L., Jr., and R. H. Kratzer, The Effects of Dietary Cobalt on Growing Chicks and Rats, Poultry Science 39(5): 1302, 1960.

Schweiger, G., The Toxic Action of Heavy Metal Salts on Fish and Organisms on which Fish Feed, Arch. Fisch Wiss. 8, 54, 1957; Water Pollution Abs. 34: 9, 1744, 1961.

Jones, J. R. E., The Relation Between the Electrolytic Solution Pressures of the Metals and Their Toxicity to the Stickleback Gasterosteus aculeatus (L.), Jour. Exp. Biol 16, $425,1939$.

Southgate, B. A., Treatment and Disposal of Industrial Wastewaters, Department of Scientific and Ind. Res., H. M. Stationary Office, London, 1948.

National Acadeny of Sciences and National Academy of Engineering, Water Quality Criteria, 1972, Environmental Protection Agency, EPA-R3-73-033, 1972.

Russel, F. C., Minerals in Pasture, Deficiencies and Excesses in Relation to Animal Health, Imperial Bur. of Animal Nutrition, Aberdeen, Scotland, Tech. Communications 15, 1944. 
Harvey, R. S., Temperature Effects on the Sorption of Radionuclides by Aquatic Organisms, In: J. W. Gibbons and R. R. Sharitz (Eds.) Thermal Ecology (Conf. 730505) NTIS, Springfield, VA, 1974.

Jones, J. R. E., A Further Study of the Relation Between Toxicity and Solution Pressure with Polycelis nigra as a Test Animal, Jour. Exp. Biol. 17, 408, 1940.

Oshima, S., On the Toxic Action of Dissolved Salts and Their lons upon Young Eels,

Anguilla japonica, Jour. imp. Fisheries Exp. Sta. (Japan) 2, 139, 1931; Jour. Water Pollution Control Fed. 32, 67, 1960.

Iwao, T., Comparative Investigations of the Toxicity of Various Metals, Jour. Exptl. Pharm. (Japan) 10, 357, 1936; Jour. Water Poilution Control Fed. 32, 67, 1960.

\section{Biological Effects of Lithium Releases}

J. E. McKee and H. W. Wolf, eds., Water Quality Criteria, 2nd Ed., Resources Agency of California, State Water Resources Control Board, Publ. No. 3-A, 548 p., 1971.

American Public Health Association, Standard Methods for the Examination of Water and Wastewater, 13th edition, A.P.H.A., Washington, DC, p 874, 1971.

M. N. Hansen and R. Overstreet, Elongation of Seedlings as Biological Test of Alkali Salts, I-Effects of Ions on Elongation, Soil Sci. 73:375-326, 1952.

D. Bertrand, Distribution of Lithium in Seeds, Chem. Biol., 31: 5-7, 1949.

G. Michael and E. Wilberg, Material Absortion in Plants, Il, Absorption of Lithium in Rye Seedlings, Z. Pflanzenernahr, Dungung Bodenk, 52:242-58, 1951.

N. Yamagata and T. Karobe, "Absorption of Rare Alkali Metals by Plants," J. Chem. Soc., Japan, Pure Chem. Sect. 72:944-7, 1951.

Leone, I. A., E. G. Brennan, R. H. Daines, and W. R. Robbins, Some Effects of Fluorine on Peach, Tomato, and Buckweat When Absorbed Through the Roots, Soil Sci. 66(4): 259-266, 1948.

Brewer, R. F., H. D. Chapman, F. H. Sutherland, and R. B. McColloch, Effect of Fluorine Additions to Substrate on Navel Orange Trees Grown in Solution Cultures, Soil Sci. 87(4): 183-188, 1959.

MacIntire, W. H., S. H. Winterberg, J. G. Thompson, and B. W. Hatcher, Fluorine Contents of Plants, Ind. Eng. Chem. 34: 1469-1479, 1942.

Treshow, M., Environmental and Plant Response, McGraw-Hill Book Co, New York, p 422, 1970.

Brewer, R. F., Effects of Hydrogen Fluoride Gas on Seven Citrus Varieties, Proc. Amer. Soc. Hort. Sci. 75: 236-243, 1960.

Anderson, F. K., Air Pollution Damage to Vegetation in Georgetown Canyon, Idaho, K.S. Thesis, University of Utah, p 102, 1966.

Aso, K., On a Stimulating Action of Calcium Fluoride on Phaenerogams, Bull. Coll. Agr. Imp. Univ. Tokyo 7: 85-90, 1906.

Treshow, M., F. K. Anderson, and F. Harner, Responses of Douglas Fir to Elevated Atmosphieric Fluorides, Forest Sci. 13(2): 144-120, 7967.

Leonard, C. D., and H. B. Graves, Effect of Air-borne Fluoride on Valencia Orange Fields, Proc. Fla. State Hort. Soc. 79: 79-86, 1966.

R. C. King, Effect of Alkali Metal Ions on Development of Drosophila, with Special Reference to Lithium Induced Abnormalities, Proc. National Acad. Sci. 39:403, 1953. 
R. D. Creek, P. Lund, O. P. Thomas and W. O. Pollard, The Effect of Lithium Carbonate on Egg Shell Formation and Serum Calcium Level of the Hen, Poul. Sci. 50(2):577-580, 1971.

P. Simonin and A. Pierron, Acute Toxicity of Fluorine Compounds, Compt. Rend. Soc. Biol., 124, 133, 1937.

G. Bringmann and R. Kuhn, Water Toxicity Studies with Protozoans as Test Organisms, Gesundeits - Ing. 80, 239, 1959.

E. P. Karlander and R. W. Krauss, Absorption and Toxicity of Beryllium and Lithium in Chlorella vanielii Shirira and Krauss, Chesapeake Sci. 14, 4:245-253, 1972.

B. G. Anderson, The Apparent Thresholds of Toxicity of Daphnia rnagna for Chlorides of Various Metals When Added to Lake Erie Water, Trans. Amer. Fish. Soc., 78, 96, 1948.

G. Bringmann and R. Kuhn, The Toxic Effects of Waste Water on Aquatic Bacteria. Algae, and Small Crustaceans, Gesundheits - Ing. 80, 115, 1959.

E. S. Hodgson, Reaction Thresholds of an Aquatic Beetle, Laccophilus maculosis, to Salts and Alcohols, Physiol. Zool. 24, 131, 1951.

C. P. Raven, Cyclopic Embryos of the Pond Snail, Limmaea stagnalis, produced by the Action of Lithium, Acta, Anat. 4, 239-47, 1947.

W. L. M. Geilenkirchem, Differences in Lithium Effects in Limmnaea after Treatment of Whole Egg-Masses and Isolated Egg Capsules, Proc. Koninkl. Nederland, Akad. Wetenschap. 55C 192-196, 1952.

H. Emanuelson, Effects of Lithium Chloride on Embryos of Ophryotrocha labronica LaCreca and Bacci, Whilhelm Roux Arch. Entwick-Lungsmech Org. 168(1): $10-19,1971$.

N. Farinella-Ferruzza, The Effect of Lithium Chloride on Ascidian Eggs, Ricerca Sci. 22, 111193-12000, 1952.

M. M. Ellis, Detection and Measurement of Stream Pollution, (related principally to fish life), U.S. Dept. of Commerce, Bur of Fisheries Bull:22, 1937.

P. Doudoroff and M. Katz, Critical Review of Literature on the Toxicity of Industiral Wastes and Their Components to Fish. II. The Metals, as Salts, Sewage and Industrial Wastes 25,802, 1953.

F. Meinck, H. Stoof and H. Hohlshutter, Industrial Waste Waters, Industrie - Agwasser, 2nd Edition, Gustav Fisher Verlag, Stuttgart 536, 44 D.M., 1956.

P. L. Hibbard, The Significance of Mineral Matter in Water, Jour. AWWA Vol. 21, p. 884, 1934.

J. M. Arena, Poisoning, C. C. Thomas, Publ., Springfield, III _ , p. 440, 1963.

\section{Biological Effects of Sodium and Potassium Releases}

American Public Health Association, Standard Methods for the Examination of Water and Wastewater, 13 th edition, A.P.H.A., Washington, DC, 1971.

Daubenmire, R. F., Plants and Environment, John Wiley and Sons, Inc., 1967.

Hagen, R. M., H. R. Haise, and T. W. Edminoter, Irrigation of Agricultural Lands, Agronomy No. 77, American Society of Agronomy, 1967.

Henderson, D. W., W. C. Bianchi, and L. D. Doneen, Amnonia Loss from Sprinkler Jets, Agr. Eng. 36: 398-399, 1955. 
Shields, L. M. and C. W. Durre11, Algae in Relation to Soil Fertility, Bot. Rev. 30, 92-128, 1964.

Fairchild, E. D. and L. L. Wilson, the Algal Flora of Two Washington Soils, Ecology 48: 1053-1055, 1967.

National Academy of Sciences and National Academy of Engineering, Water Qua! ity Criteria, 1972, Environmental Protection Agency, EPA-R3-73-033, p 527, 1972.

Gentile, J. H. and T. E. Maloney, Toxicity and Environmental Requirements of a Strain of Aphanizomenonlos-Aquce (L.) Ralfs, Can. J. Microbiol. 15: 165-173, 1969.

Davis, P. and G. W. Ozburn, the pH Tolerance of Daphnia pulex, Can. J. Zool. 47: 1173-1175, 1969.

O'Brien, J. W. and F. DeNoyelles, Jr., Photosynthetically Elevated pH as a Factor in Looplankton Mortality in Nutrient Enriched Ponds, Ecology 54(4): 605-614, 1972.

Jones, J. R. E., A Study of the Relative Toxicity of Anions with Polycelis nigra as a Test Animal, J. Exp. Biol. 18: 170-181, 1941.

Roback, S. S., Environmental Requirements of Tricoptera, Biological Problems in Water Pollution, Third Seminar, Aug 13-17, p 118-126, 1962.

Curry, L. L., A Survey of Environmental Requirements for the Midge, Biological Problems in Water Pollution, Third Seminar, Aug 13-17, p 117-141, 1962.

Jones, J. R. E., A Further Study of the Reactions of Fish to Toxic Solutions, J. Exp. Biol, 25: $22-34,1948$.

Jones J. R. E., Fish and River Pollution, In: L. Klein (ed) Aspects of River Pollution, Butterworth Scientific Publications, London, 1957.

Jordon, D. H. M. and R. Lloyd, The Resistance of Rainbow Trout, Salmo qairdneri Richardson, and Roach, Rutilis nutilis (L.), to Alkaline Solutions, Int. J. Wat. Poll. 8: 405-409, 1964.

Krishna, D. Effect of Changing pH on Ueveloping Trout Eggs and Larvae, Nature 171: 434, 1953.

Wieb, A. H., A. M. McGavock, A. C. Fuller, and H. C. Markus, The Ability of Freshwater Fish to Extract Oxygen at Different Hydrogen-ion Concentrations, Physiol Zool. 7: 435-448, 1934.

Cairns, J. Jr., K. L. Dickson, and J. J. Crossman, The Biological Recovery of the Clinch River Following A Fly Ash Pond Spill, Proc. 25th Ind. Waste Conf. Purdue University, p 182-192, 1970.

Seifriz, W., Toxicity and the Chemical Properties of lons, Science 110: 193-196, 1949.

Strogonov, B. P., Physiological Basis of Salt Tolerance of Plants, Daniel Davey and Co., Iric., 7964.

Meiri, A and A. Poljakoff-Mayber, Effect of Various Salinity Regimes on Growth, Leaf Expansion and Transpiration Rate of Bean Plants, Soil Sci. 190: 26-34, 1370.

Eernstein, L., Effects of Salinity on Mineral Composition and Growth of Plants, Plant Analysis and Fertilizer Problems, IV, p 25-45, 1964.

LaHayne, P. A. and E. Epstein, Salt Toleration by Plants: Enhancement with Calcium, Science 166: $395-396,1969$.

Raabe, R. D., J. Vlamis, J. H. Huliman, and J. Quick, Sodium Injury of Cuttings of Chrysanthemums, Calif. Agr. 20: 11-13, 1966.

Ayers, A. D., Salt Tolerance of Avocado Trees Grown in Cultural Solution, Calif. Avocado Soc. Yearbook, p 139-148, 1950.

Treshow, M., Environmental and Plant Response, McGraw-Hill Book Co., New York, 1970. 
Choudhuri, G. N., Effect of Soil Salinity on Germination and Survival of Some Steppe Plants in Washington, Ecology 49: 465-471, 1968.

Biesinger, K. E. and G. M. Christensen, Effects of Various Methods on Survival, Growth, Reproduction, and Metabolism of Daphnia magna, J. Fish. Res. Bd. Can. 29: 1691-1700, 1972.

Freeman, L. and I - Fowler, Toxicity of Combinations of Certain Inorganic Compounds to Daphnia magna Straus, Sew. Ind. Wastes 25: 1191-1195.

Doudoroff, P. and M. Katz, Critical Review of Literature on the Toxicity of Industrial Wastes and Their Components to Fish. I. Alkalis, Acids, and Inorganic Gases, Sew. Ind. Wastes

22: $1432,1950$.

Finley, H. E., Tolerance of Freshwater Protozoa to Increased Salinity, Ecology 11: 337-347, 1930.

Gordon, M. S., Ionic Regulations in the Brown Trout, Salmo trutta (L.), J. Exp. Biol. 36: 227-250, 1959.

\section{Biological Effects of Beryllium Releases}

American Public Health Association, Standard Methods for the Examination of Water and Wastewater, 13th edition, A.P.H.A., Washington, DC, 1971.

Hopkins, H. T., Inhibition of Growth by Benzene Hexachloride Isomers and Protective Effect of Glucose as Measured by Cell Counting Technique, Plant Physiol. 27: 526-540, 1952.

Romney, E. M., J. D. Childress, and G. V. Alexander, Beryllium and the Growth of Bush Beans, Science 135: 786-787, 1962.

Vorwald, A. J., Medical Aspects of Beryllium Disease, In: H. E. Stokinger (ed), Beryllium, Its Industrial Hygiene Aspects, p 167-200, Academic Press, New York, 1966.

Breslin, A. J., Community Aspects, In: H. E. Stokinger (ed), Beryllium, Its Industrial Hygiene Aspects, p 329-355, 1966.

Arena, J. M., Poisoning, Charles C. Thomas Publ., Springfield, IL, 1963.

Goldberg, E. D., W. S. Broecker, M. G. Gross, and K. K. Turekion, Marine Chemistry, In:

National Academy of Sciences, Radioactivity in the Marine Environment, p 137-146, 1971.

Karlonder, E. P. and R. W. Krauss, Absorption and Toxicity of Beryllium and Lithium in Chlorella varınielii Shihira and Krauss, Chesapeake Science 13: 245-253, 1972.

Tarzwell, C. M. and C. Henderson, Toxicity of Less Common Metals to Fishes, Industrial Wastes $5, \quad 12,1960$.

Jackim, E., M. Hamlin, and S. Sonis, Effects of Metal Poisoning on Five Liver Enzymes in the Killifish, Fundulus heteroclitus. J. Fish. Res. Board Can. 27(2): 383-390, 1970. 


\section{OFFSITE}

A. A. Churm

ERDA Chicago Patent Group

9800 S. Cass Avenue Argonne, IL 60439

J. W. Beal

ERDA Div. of Magnetic Fusion Energy

Washington, D 20545

S. 0. Dean

ERDA Div. of Magnetic

Fusion Energy

Washington, DC 20545

E. E. Kintner

ERDA Div. of Magnetic

Fusion Energy

Washington, $\quad 20545$

J. M. Williams

ERDA Div. of Magnetic

Fusion Energy

Washington, \& 20545

J. N. Grace

ERDA Div. of Magnetic

Fusion Energy

Washington, DC 20545

J. Baublitz

ERDA Oiv. of Magnetic

Fusion Energy

Washington, DC 20545

3 F. E. Coffman

ERDA Div. of Magnetic

Fusion Energy

Washington, D 20545

J. F. Decker

ERDA Div. of Magnetic

Fusion Energy

Washington, DC 20545

3 K. M. Zwilsky

ERDA Div. of Magnetic

Fusion Energy

Washington, × 20545

Dr. Philip M. Stone

ERDA Applied Plasma Physics

Program

Washington, DC 20545

G. W. Kuswa

ERDA Div. of Laser Fusion

Washington, X 20545
R. Blaunstein

ERDA Div. of Biomedical and Environmental Research

Washington, D 20545

H. M Busey

ERDA Div. of Military

Application

Washington, \& 20545

M. A. Bell

EROA Oiv. of Safety

Standards and Compliance

Washington, DC 20545

27 ERDA Technical Information Center

M. S. Kaminsky

Argonne National Laboratory

9700 S. Cass Avenue

Argonne, IL 60439

V. A. Maroni

Argonne National Laboratory

9700 S. Cass Avenue

Argonne, IL 60439

P. M. Persiani

Argonne National Laboratory

9700 S. Cass Avenue

Argonne, IL 60439

M. Petrick

Engineering and Technology

Division

Argonne National Laboratory

9700 S. Cass Avenue

Argonne, IL 60439

W. E. Parkins, Manager

Atomics International

Component Engineering and

Technology Division

North American Rockwell

P.O. Box 309

Canoga Park, CA 91304

D. Gurinsky

Brookhaven National Laboratory

ERDA Brookhaven Area Office

Upton, NY 11973

H. J. Kouts

Brookhaven National Laboratory

ERDA Brookhaven Area Office

Upton, NY 11973

S. Pearlstein

Brookhaven National Laboratory ERDA Brookhaven Area Office Upton, NY 11973 $\underline{\text { OFFSITE }}$

J. R. Powell

Brookhaven National Laboratory ERDA Brookhaven Area Office

Upton, NY 11973

A. J. Impink, $\mathrm{Jr}$.

Carnegie Mellon University

Pittsburgh, PA 15213

R. A. Gross

Plasma Research Laboratory

236 SN Mudd BIdg.

Columbia University

New York, NY 10027

W. C. Gough

Electric Power Research Inst.

3412 Hillview Ave.

Palo Alto, CA 94304

G. R. Hopkins

Gulf General Atomic

P.O. Box 1111

San Diego, CA 92112

Zeinab Sabri

lowa State University

261 Sweeney Hal 7

Nuclear Engineering Department

Ames, IA 50010

R. Borg

Lawrence Livermore Laboratory

P.O. Box 808

Livermore, CA 94550

T. K. Fowler

Lawrence Livermore Laboratory

P.O. Box 808

Livermore, CA 94550

R. Moir

Lawrence Livermore Laboratory

P.O. Box 808

Livermore. CA 94550

A. Carl Haussmann

Lawrence Livermore Laboratory

P.O. Box 808

Livermore, CA 94550

J. Hovingh

Lawrence Livermore Laboratory

P.O. Box 808

Livermore, CA 94550

R. F. Post

Lawrence Livermore Laboratory

P.O. Box 808

Livermore, CA 94550

C. J. Taylor

Lawrence Livermore Laboratory

P.O. Box 808

Livermore, CA 94550 
R. Werner Lawrence Livermore

Laboratory

P.O. Box 808

Livermore, CA 94550

L. L. Wood

Lawrence Livermore

Laboratory

P.O. Box 808

Livermore, CA 94550

W. Bauer

Division Supervisor

of Physical Research

Sandia Labs Livermore

Livermore, CA 94550

L. Booth

Los Alanios Scientific

Laboratory

CTN Research

P.O. Box 1663

Los Alamos, MM 87544

D. J. Dudziak

Los Alamos Scientific Laboratory

CTN Research

P.O. Box 1663

Los Alamos, M 87544

D. B. Henderson

Los Alamos Scientific

Laboratory

CTN Research

P.O. Box 1663

Los Alamos, M 87544

E. L. Kemp

Los Alamos Scientific

Laboratory

CTN Research

P.O. Box 1663

Los Alamos, M 87544

F. L. Ribe

Los Alamos Scientific

Laboratory

CTN Research

P.O. Box 1663

Los Alamos, NM 87544

L. Stewart

Los Alamos Scientific

Laboratory

CTN Research

P.O. Box 1663

Los Alamos, M 87544

K. Thomassen

Los Alamos Scientific

Laboratory

CTN Research

P.O. Box 1663

Los Alamos, M 87544
0. K. Harling

Massachusetts Institute of

Technology

Cambridge, MA 02139

Bruno Coppi

Department of Physics

Massachusetts Institute of

Technology

Cambridge, MA 02139

L. Lidsky

Dept. of Nuclear Engineering Massachusetts Institute of

Technology

Cambridge, MA 02139

Norm Rasmussen

Dept. of Nuclear Engineering Massachusetts Institute of

Technology

Cambridge, MA 02139

David Rose

Massachusetts Institute of

Technology

Cambridge, MA 02139

R. E. Stickney

Mechanical Engineering

Massachusetts Institute of

Technology

Cambridge, MA 02139

J. J. Reinmann

NASA - Lewis Research Center

2100 Bookpark Rd.

Cleveland, 어 44135

Vincent Arp

National Bureau of Standards

Cryogenics Division

Boulder, CO 80302

J. F. Clarke

Oak Ridge National

Laboratory

P.O. Box Y

Oak Ridge, TN 37830

A. P. Fraas

Oak Ridge National

Laboratory

P.O. Box Y

Oak Ridge, TN 37830

J. Rand McNally, Jr.

Oak Ridge National

Laboratory

P.O. Box Y

Oak Ridge, TN 37830

D. Steiner

Oak Ridge National

Laboratory

P.O. Box Y

Oak Ridge, TN 37830

\section{OFFSITE}

J. Scott

Oak Ridge National Laboratory

P. 0. Box $X$

Oak Ridge, $\mathbb{T N} 37830$

J. Banford

Physics International

2700 Merced St.

San Leandro, CA 94577

R. A. Huse

Public Service Electric

and Gas Co.

80 Park Place

Newark, NJ 07101

M. Gottlieb

Princeton University, PPPL

P.O. Box 451

Princeton, NJ 08540

R. G. Mills

Princeton University

P.O. Box 451

Princeton, NJ 08540

E. C. Tanner

Princeton University

P.O. Box 451

Princeton, NJ 08540

H Perkins

Dept. of Chemistry

Princeton University

Princeton, NJ 06540

R. E. Gold

303 Sayre $\mathrm{Hal} 1$

Forrestal Campus

P.O. Box 451

Princeton, NJ 06540

M. Kristiansen

Texas Tech. University

Lubbock, TX 79409

A. F. Haught

United Aircraft Research Lab.

United Aircraft Corporation

East Hartford, CT 06108

L. Levine

U.S. Naval Research Laboratory

Washington, DC 20390

C. Z. Serpan, Jr.

U.S. Naval Research Laboratory

Washington, DC 20390

Francis Chen

University of California

Electronics Research

Laboratory

College of Engineering

Berkeley, CA 94720 
A. J. Lichtenberg

University of California

Electronics Research

Laboratory

College of Engineering

Berkeley, CA 94720

Dave Okrent

U.C.L.A.

Los Angeles, CA 90024

C. D. Hendricks

University of Illinois

Nuclear Engineering

Laboratory

Urbana, IL 61801

G. H. Miley

University of Illinois

Nuclear Engineering

Laboratory

Urbana, IL 61801

Terry Kammash

University of Michigan

Nuclear Engineering

Department

Ann Arbor, M I 48105.

Dean Abrahamson

University of Minnesota

School of Public

Affairs

Social Science

Building/309

Minneapolis, MN 55455

W. G. Davey

University of Texas

Department of Physics

Austin, TX 78712

E. Linn Draper, Jr.

University of Texas

Department of Physics

Austin, TX 78712

W. E. Drummond

University of Texas

Department of Physics

Austin, TX 78712

Abraham Hertzberg

University of Washington

Aerospace Research

Laboratory

316 Guggenheim

Seattle, WA 98105

A. L. Babb

University of Washington

Nuclear Engineering

Department

Seattle, WA 98105
R. Conn

University of Wisconsin

Nuclear Engineering

Department

Madison, WI 53706

G. L. Kulcinski

University of Wisconsin

Nuclear Engineering

Department

Madison, WI 53706

C. W. Maynard

University of Wisconsin

Nuclear Engineering

Department

Madison, WI 53706

D. Lichtman

Department of Physics

University of Wisconsin

Milwaukee, WE 53201

E. E. Donaldson

Washington State University

Deparment of Physics

Pullman, WA 99163

D. D. Mahlum

Division of Biomedical and Environmental Research

Washington, DC 20545

J. V. Vanston

Engineering Science

Building

University of Texas

Austin, TX 78712

Leslie S. Ramsey

450 North 5 th Street

Indiana, PA 15701 
ERDA Richland Operations Office

W. A. Burns

Atlantic Richfield Hanford Company

J. D. Kaser

Hanford Engineering

Development Labs

D. G. Doran

H. H. Yoshikawa

\section{$\underline{\text { Battelle-Northwest }}$}

D. T. Aase

G. S. Allison

T. W. Ambrose

D. G. Atteridge

D. A. Baker

J. L. Bates

M. A. Bayne

E. R. Bradley

J. L. Brimhall

R. L. Brodzinski

R. J. Brouns

L. R. Bunnell

L. L. Burger

S. H. Bush

N. E. Carter

T. D. Chikalla

R. G. Clark

T. L. Criswell

S. D. Dahlgren

M. T. Dana

D. E. Deonigi

R. L. Dillon

D. A. Dingee

P. J. Dionne

B. H. Duarle

J. W. Finnigan

J. C. Fox

J. J. Fuquay

J. E. Garnier

R. D. Gastil

B. F. Gore

J. N. Hartley

A. J. Haverfield

U. P. Jenquin

A. B. Johnson, Jr.

R. $\mathrm{H}$. Jones

T. J. Kabele

W. S. Kelly

H. E. Kissinger

D. A. Kottwitz

N. Laegried

B. R. Leonard, Jr

D. L. Lessor

H. B. Liemohn

R. C. Liikala

M. A. Mckinnon

R. F. Maness

R. P. Marshall
Battelle-Northwest - Continued

E. S. Murphy

R. D. Nelson

D. F. Newman

R. E. Nightingale

D. E. Olesen

L. T. Pedersen

R. T. Perry

D. R. Pratt

L. A. Rancitelli

J. F. Remark

U. S. Renné

R. E. Rhoads

W. D. Richmond

W. F. Sandusky

L. C. Schmid

N. M. Sherer

E. P. Simonen

R. I - Smith

J. K. Soldat

C. W. Stewart

K. B. Stewart

R. W. Stewart

10 J. A. Strand

D. L. Styris

A. M. Sutey

V. L. Teofilo

G. L. Tingey

M. T. Thomas

R. C. Thompson

L. H. Toburen

T. J. Trapp

R. Wang

R. E. Westerman

L. D. Williams

10 J. R. Young

M. G. Zimmerman

1 Technical Publications (BH)

5 Technical Information

Distr-4 